\author{
CLAUDIA BRITTENHAM \\ DEBRA NAGAO \\ UNIVERSITY OF CHICAGO/INDEPENDENT SCHOLAR
}

\title{
Cacaxtla Figural Ceramics
}

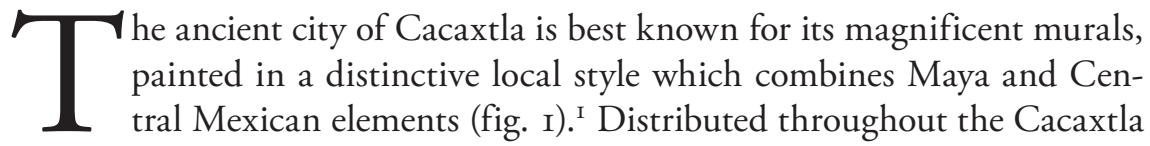
acropolis, and corresponding to different moments of construction between A.D. 600-950, these murals were the public face of the city during the Epiclassic period, both their content and their style announcing Cacaxtla's cosmopolitan associations with the exotic riches of the tropical south. Yet the focus on Cacaxtla's murals has threatened to overshadow the significance of other kinds of material culture found at the site, which can provide a valuable

I. There is an extensive literature on the Cacaxtla murals, including Rafael Abascal, Patricio Dávila et al., "La arqueología del sur-oeste de Tlaxcala (primera parte)," Comunicaciones del Proyecto Puebla-Tlaxcala, Suplemento II (Puebla: Fundación Alemana para la Investigación Científica, 1976); Claudia Brittenham, The Murals of Cacaxtla: The Power of Painting in Ancient Central Mexico (Austin: University of Texas Press, forthcoming); Marta Foncerrada de Molina, Cacaxtla: la iconografía de los olmeca-xicalanca, ed. Emilie Carreón (Mexico City: Universidad Nacional Autónoma de México-Instituto de Investigaciones Estéticas, 1993); George A. Kubler, "Eclecticism at Cacaxtla," in Tercera Mesa Redonda de Palenque, 1978, Part 2, eds. Merle Greene Robertson and Donnan C. Jeffers (Monterrey: Pre-Columbian Art Research Center, I980); Sonia Lombardo de Ruiz, "La pintura," in Cacaxtla: el lugar donde muere la lluvia en la tierra (Mexico City: Gobierno del Estado de Tlaxcala and Instituto Nacional de Antropología e Historia, 1986); Donald Robertson, "The Cacaxtla Murals," in Fourth Palenque Round Table, I980, ed. Elizabeth P. Benson (San Francisco: Pre-Columbian Art Research Institute, 1985); La Pintura Mural Prehispánica en México, t. V, Cacaxtla, Estudios, 2 vols., eds. María Teresa Uriarte and Fernanda Salazar Gil (Mexico City: Universidad Nacional Autónoma de México-Instituto de Investigaciones Estéticas, 2013). 


\section{CLAUDIA BRITTENHAM - DEBRA NAGAO}

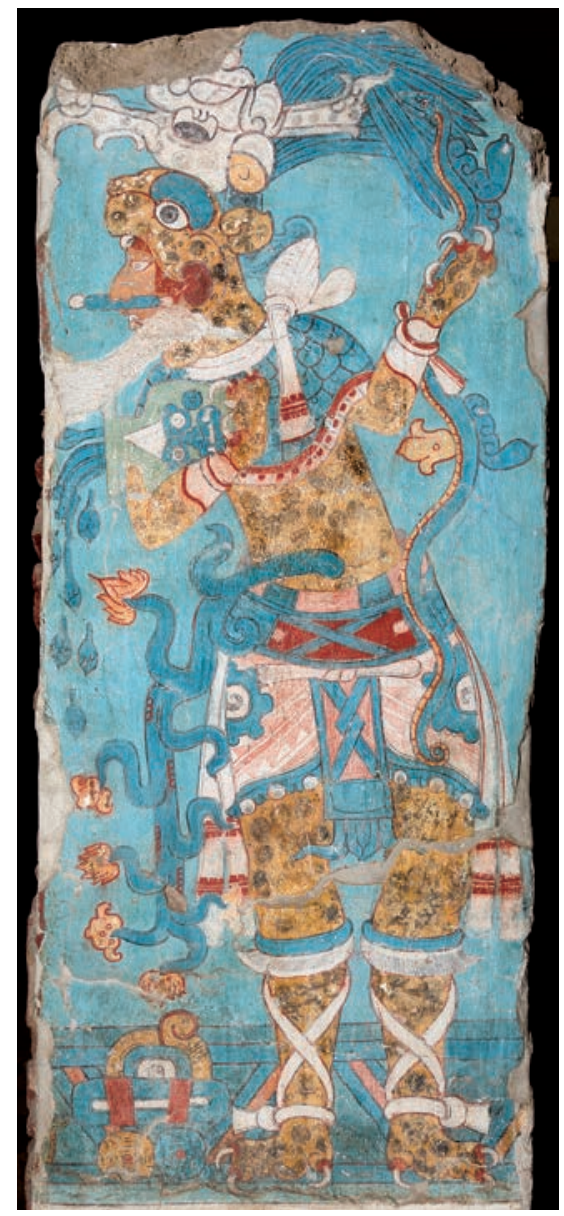

I. Cacaxtla, Structure A, north jamb mural. Photo: Ricardo Alvarado Tapia and María de Jesús Chávez Callejas, courtesy of the project "La pintura mural prehispánica en México," iIe, unam. Conaculta-Inah-méx. "Reproducción autorizada por el Instituto Nacional de Antropología e Historia."

counterpoint to the narratives of identity promoted by the paintings. ${ }^{2}$ In this paper, we analyze another category of objects - figural ceramics-for the competing, and at times contradictory, evidence that they provide about $\mathrm{Ca}$ caxtla's history (fig. 2). In particular, we argue that a group of clay sculptures,

2. Debra Nagao, "Public Proclamation in the Art of Cacaxtla and Xochicalco," in Mesoamerica After the Decline of Teotihuacan, A.D. 700-900, eds. Richard A. Diehl and Janet Catherine Berlo (Washington, D.C.: Dumbarton Oaks Research Library and Collection, 1989). 


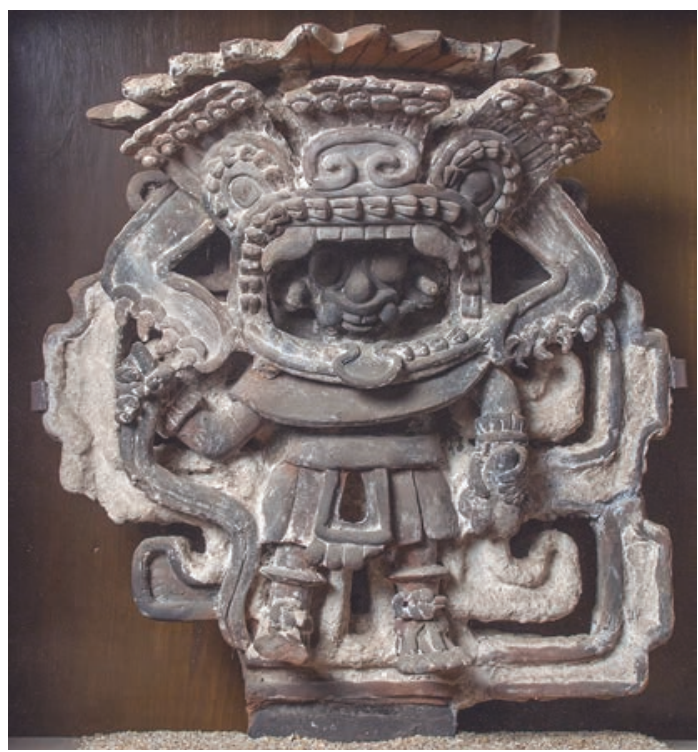

2. Cacaxtla, Once Señores, figure with jaguar headdress. Museo de Sitio de Cacaxtla. Photo: (C) Marco Antonio Pacheco. Conaculta-InAH-MÉx. "Reproducción autorizada por el Instituto Nacional de Antropología e Historia."

the so-called "Once Señores," discovered in I998 near Cacaxtla, may offer new information about Cacaxtla's relationship with Teotihuacan during the Classic period (A.D. Ioo-60o), expanding our understanding of the ways that the citizens of Cacaxtla used art as a political tool. ${ }^{3}$

3. In this text, we use the term Classic to refer to the period between the first and sixth centuries A.D., when Teotihuacan was the major power in Central Mexico, and the term Epiclassic to refer to the period after the fall of Teotihuacan and before the rise of Tula, ca. A.D. 600-950. In the Maya area, chronological terminology is slightly different, describing an Early Classic period from A.D. 200-550/600, a Late Classic period between A.D. 600 and 800, and Terminal Classic period running from A.D. 800 to Iooo. For further discussion of terminology, see also the essays in Diehl and Berlo, Mesoamerica After the Decline of Teotihuacan; Enrique Nalda, "El Epiclásico: una noción restrictiva," in Arqueología mexicana, historia y esencia, siglo XX. En reconocimiento al doctor Román Piña Chán, ed. Jesús Nava Rivero (Mexico City: Instituto Nacional de Antropología e Historia, 2002). 
Although previous commentators have noted formal and iconographic similarities between the Once Señores and the art of Teotihuacan, ${ }^{4}$ the significance of these parallels, and their implications for the study of Cacaxtla, have not yet been fully appreciated. What is important about the Once Señores is that they demonstrate a different relationship with the art of Teotihuacan than the murals and other works of art that have been found at Cacaxtla. The paintings discovered at Cacaxtla to date speak of a deliberate election of Maya style, and a concomitant rejection of things Teotihuacano. By contrast, the Once Señores demonstrate considerable engagement with Teotihuacan iconography and ceramic traditions, and Maya art is nearly absent from this dialogue. Yet the Once Señores are not exact copies of foreign models. Instead, like the murals, they demonstrate how artists and patrons at Cacaxtla reformulated art and ideas from outside the city-state in order to meet local needs.

After briefly describing the Once Señores and the archaeological context from which they were recovered, we review the iconography of these figures and their parallels with the art of Teotihuacan and other Mesoamerican traditions. We then compare the Once Señores to other figural ceramics recovered at Cacaxtla. We conclude by analyzing two proposals for the divergence between the Once Señores and the other art of Cacaxtla: either that they represent concurrent but distinct artistic strategies, or that the Once Señores are earlier than the murals and associated artifacts, documenting a previous moment of using art as a political strategy to announce foreign affiliation.

\section{The Once Señores}

The set of eleven terracotta figures known as the "Once Señores" (the "Eleven Lords") were discovered in 1998 on a hillside 800 meters to the east of the Cacaxtla acropolis, in the garden of the Cadena Benítez family in the community of San Miguel del Milagro. 5 This was not the original location or context for these

4. David A. Morales Gómez, "Rescate de las esculturas de los Once Señores de Cacaxtla, en San Miguel del Milagro, Tlaxcala," Arqueología. Revista de la Coordinación de Arqueología 22 (1999): I59-I63; Francisco Rivas Castro and Claudia Michetti Micó, "Iconografía y simbolismo de los Once Señores de Cacaxtla," in Memorias del Primer Coloquio Internacional Cacaxtla a sus treinta años de investigación (Tlaxcala: Centro Regional INAH-Tlaxcala, 2007), 447-463.

5. Morales Gómez, "Rescate de las esculturas de los Once Señores”; Virginia Bautista, "Custodian Once Señores Museo de Cacaxtla," Reforma, 9 $9^{\text {th }}$ August, 2000. 
objects, but rather an intentional and meaningful deposit: ten of the sculptures were reportedly found buried in pairs, face-down, with the remaining figure standing nearby. ${ }^{6}$ The deposit consisted solely of these ceramics, placed near a prehispanic wall-no other objects were found associated with them. Several of the sets of paired sculptures were placed at right angles, forming cross-like shapes. Similar sculptures were placed together, though no two were completely identical. The eleven sculptures can be divided into three groups, based on costume elements and other attributes: there are four figures with jaguar headdresses, four figures with bird or butterfly headdresses, and three figures with blocky, rectangular headdresses, crescent slit eyes, and o-shaped mouths.

Although the Once Señores were not found at Cacaxtla proper, they are clearly related to the site. The hill on which they were discovered formed part of the greater Cacaxtla-Xochitécatl-Nativitas settlement during the Epiclassic period, ${ }^{7}$ and related objects were discovered during excavations in and around the Cacaxtla acropolis. Archaeologists Daniel Molina Feal and Diana López de Molina excavated similar fragments within the Cacaxtla acropolis proper. ${ }^{8} \mathrm{~A}$ twelfth full figure, similar but not identical to the Once Senores, was found in 198I near the base of the western slope of the hill of Cacaxtla, face down on top of a series of twelve burials (fig. 3). ${ }^{9}$ Like several of the Once Señores, this figure standing against an openwork geometric background displays variations on the Tlaloc theme: here the figure's goggled Tlaloc mask splits open to reveal a human face with T-shaped dental mutilation. The figure holds a triangular bag and an undulating staff which resembles the objects held by the Tlaloc figures among the Once Señores. However, the backdrop is stepped and angular, rather than curving like those of the Once Señores. Finally, an urn with an attached figure was recovered on one of the terraces to the southeast of the acropolis. Its head was unfortunate-

6. Morales Gómez, "Rescate de las esculturas de los Once Señores," I57-I59; Rivas Castro and Michetti Micó, "Iconografía y simbolismo de los Once Señores de Cacaxtla," 44I.

7. Mari Carmen Serra Puche and Jesús Carlos Lazcano Arce, Vida cotidiana XochitécatlCacaxtla (Mexico City: Universidad Nacional Autónoma de México-Instituto de Investigaciones Antropológicas, 201 I), 37-46.

8. Diana López de Molina and Daniel Molina Feal, "Arqueología," in Cacaxtla: el lugar donde muere la lluvia en la tierra (México: Gobierno del Estado de Tlaxcala and Instituto Nacional de Antropología e Historia, 1986), figs. I36, 140.

9. Roberto Jiménez Ovando, "Entierros humanos prehispánicos de la zona arqueológica de Cacaxtla, Tlaxcala," Antropológicas 2 (1988): 57-72, figs. 7 y 8. 
60

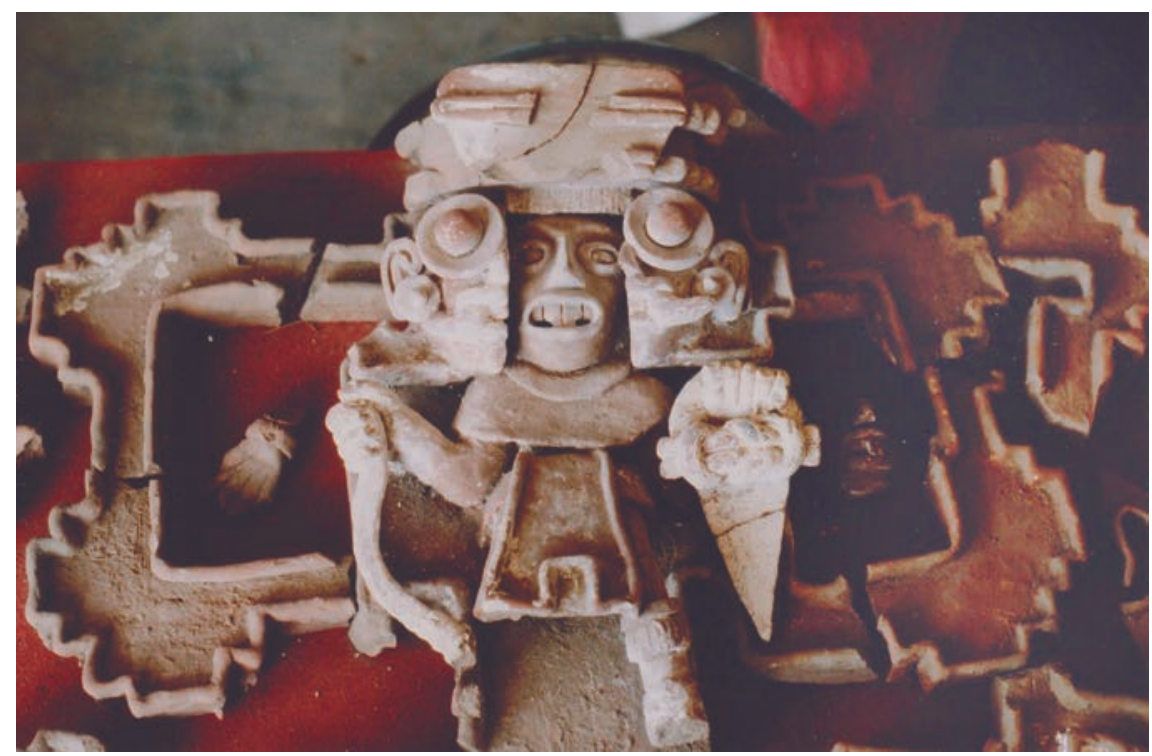

3. Cacaxtla, figure resembling the Once Señores found during excavations on the Acropolis in 198I. Now in the Museo Regional de Tlaxcala. Photo: Debra Nagao. Conaculta-InahMÉx. "Reproducción autorizada por el Instituto Nacional de Antropología e Historia."

ly not among the fragments recovered, but its costume is similar to that of the Once Señores, and like the figure found in 198I, it holds an undulating staff and a triangular incense bag. ${ }^{\mathrm{I}}$ These finds clearly demonstrate that the Once Señores are related to Cacaxtla and not the product of a separate tradition.

Each of the Once Señores measures $40-45 \mathrm{~cm}$ in height, and consists of two components: an openwork geometric background with a tenon at its base and the figure, which was attached to it. Although largely masked by the standing figures and their elaborate regalia, the grid-like backdrop consists of three stacked pairs of frets or volutes, the forms softly rounded with a curl in the interior. A thick band of clay outlines the inner and outer contours, giving the illusion of a double outline. The fret bears a certain resemblance to a rectangular rendition of a cross-sectioned conch shell. ${ }^{I I}$ The figure in turn is composed of

Io. Rosalba Delgadillo Torres, "Las urnas policromadas de Cacaxtla, Tlax. (Estudio preliminar)," in Memorias del Primer Coloquio Internacional Cacaxtla a sus treinta años de investigación (Tlaxcala: Centro Regional INAH-Tlaxcala, 2007), 480-48I.

I I. Karl A. Taube, "Tetitla and the Maya Presence at Teotihuacan," in The Maya and Teo- 
a visibly human face and body covered with insignia_clothing, a headdress, and other attributes - each component modeled separately and attached to the core body. Some elements, especially the faces of the bird and butterfly figures, appear to be mold-made, but many are hand-modeled. ${ }^{22}$ While this is clearly a unified corpus of objects, the sculptures are by no means identical, and even the most closely related pairs show substantial differences in the proportion and modeling of many elements, raising the possibility that they were created by different artists or at different moments. The finds on the acropolis may also indicate an extended period of use for these kinds of objects.

The Once Señores might have served as roof ornaments, or almenas, which projected at regular intervals from the upper level of structures throughout Mesoamerica. The long vertical tenons suggest such a function, as do the scale, the stepped shape, and openwork volutes, all which are reminiscent of roof ornaments found at Teotihuacan, Xochicalco, Tlapizahuac, and Tula. ${ }^{13}$ The flat backgrounds, minimally finished backs, and hieratic pose of the figures suggest they were intended to be viewed frontally, while the tenons at their bases indicate vertical display. Yet they are still strikingly dynamic and three-dimensional works, with layered costume elements curving and projecting into high relief, all framed by the curvilinear openwork backdrop. Although an architectural function seems most likely for these objects, none of them were found in their original context, and it is not possible to identify architectural remains that might confirm their original purpose.

tihuacan: Reinterpreting Early Classic Interaction, ed. Geoffrey Braswell (Austin: University of Texas Press, 2003), 292.

I2. Rivas Castro and Michetti Micó, "Iconografía y simbolismo de los Once Señores," 445-446.

13. Teotihuacan: Art from the City of the Gods, eds. Kathleen Berrin and Esther Pasztory, (New York and San Francisco: Thames \& Hudson and Fine Arts Museums of San Francisco, 1993), I73, 208; Escultura en piedra de Tula, Catálogo, eds. Beatriz de la Fuente, Silvia Trejo et al. (Mexico City: Universidad Nacional Autónoma de México-Instituto de Investigaciones Estéticas, 1988), ill. 90, I50; La Acrópolis de Xochicalco, eds. Beatriz de la Fuente, Silvia Garza Tarazona et al. (Mexico City: Instituto de Cultura de Morelos, 1995), ı09; Virginia Smith and Kenneth G. Hirth, "A Catalog of Carved Monuments and a Guide to the Visual Characteristics of Xochicalco's Art Style," in Archeological Research at Xochicalco: The Xochicalco Mapping Project, ed. Hirth (Salt Lake City: University of Utah Press, 2000), 50; Teotihuacan: Cité des Dieux, ed. Felipe Solís (Paris: Musée du Quai Branly and Somogy Editions d'Art, 2009), 218, 317-318, 364-367, 457; Alejandro Tovalín Ahumada, Gabriel Lalo Jacinto et al., Tlalpizahuac, Un sitio arqueológico del Postclásico Temprano (Toluca: Dirección de Arqueología del Instituto Mexiquense de Cultura, I992), 58, 61, 63. 
Before being placed in the deposit, these objects had an extended use-life: there is evidence of breakage and repair, with the joins covered with a thick layer of stucco. Some figures displayed more than six layers of stucco, apparently with no evidence of pigments on any of the layers. ${ }^{I 4} \mathrm{~A}$ final coating of stucco was applied to the objects before they were deposited in the cache, apparently to protect them; this coating was removed during conservation. ${ }^{\text {IS }}$ This evidence of long-term use, combined with the careful burial of the objects, suggests that they held a special meaning for the ancient inhabitants of Cacaxtla.

\section{The Once Señores and Teotihuacan}

These ceramics are strikingly idiosyncratic in form and style, distinct from the other ceramics found at Cacaxtla-Xochitécatl and from other Mesoamerican ceramic traditions. Yet they do demonstrate iconographic and stylistic ties to the art of Teotihuacan, citing motifs particular to the art of that city, and rendering other, pan-Mesoamerican themes, like birds and jaguars, in forms with closer parallels at Teotihuacan than elsewhere in Mesoamerica. At the same time, misinterpretations and divergences from Teotihuacan forms suggest local reworkings of metropolitan models, an impression reinforced by the technical differences between these objects and their presumptive prototypes.

Jaguars and Tlalocs

The relationships to Teotihuacan are clearest in the four figures wearing jaguar headdresses (figs. 2, 4, 5, and 6). The key features of these headdresses, including the parted, feathered brows, the curled snout, and the outcurving fangs are characteristic of Teotihuacan felines, as is the use of a jaguar headdress with the lower jaw forming a chinstrap framing the face. ${ }^{16}$ Even more

I4. Morales Gómez, "Rescate de las esculturas de los Once Señores" i59. However, for an account of color on the sculptures, see Rivas Castro and Michetti Micó, "Iconografía y simbolismo de los Once Seńores," 444-446.

I5. Morales Gómez, "Rescate de las esculturas de los Once Señores," i59. See also Pedro Morales, "Los Once Señores de Cacaxtla," http://www.argonmexico.com/index. php?option=com_content\&view=article\&id=22153.

16. George A. Kubler, "Jaguars in the Valley of Mexico," in The Cult of the Feline, ed. Elizabeth P. Benson (Washington, D.C.: Dumbarton Oaks Research Library and Collec- 
4. Cacaxtla, Once Señores, figure with jaguar headdress. Museo de Sitio de Cacaxtla.

Photo: (C) Richard Seaman, www.richard-seaman.com. Conaculta-INAH-MÉx. "Reproducción autorizada por el Instituto Nacional de Antropología e Historia."

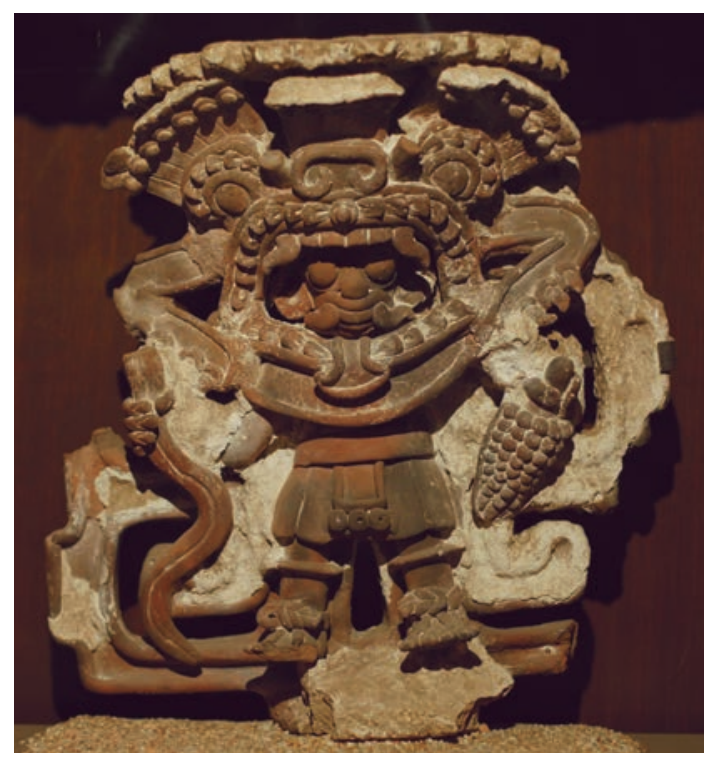

diagnostic are the descending forelegs with their ferocious claws, a convention unique to Teotihuacan imagery. This feline headdress rendered in Teotihuacan conventions contrasts sharply with Xochicalco, Maya, or Zapotec images of jaguars and jaguar headgear, which use different, more naturalistic vocabularies than the abstract, composite creatures at Teotihuacan.

Inside the jaguar headdresses, the bulging eyes of three of these figures are ringed with round goggles, a characteristic attribute of the Teotihuacan storm god Tlaloc. ${ }^{17}$ Two of the figures also have the outcurving side fangs characteristic of that deity, while the other two have front teeth filed into a T-shape. Furthermore, three of the four figures carry attributes associated with Tlaloc at Teotihuacan: a curving, serpent-like form that may represent a bolt of lightning in their right hands, and agricultural bounty-an ear of maize or

tion, I972), 25-32; Saburo Sugiyama, "Los animales en la iconografía teotihuacana," Revista Mexicana de Estudios Antropológicos 34, no. I (1988): figs. I00-I3I. Arthur G. Miller, The Mural Painting of Teotihuacán (Washington, D.C.: Dumbarton Oaks Research Library and Collection, I973), 80-8I.

17. Esther Pasztory, Iconography of the Teotihuacan Tlaloc, Studies in Pre-Columbian Art and Archaeology I5 (Washington, D.C.: Dumbarton Oaks Research Library and Collection, I974). 
64 CLAUDIA BRITTENHAM - DEBRA NAGAO

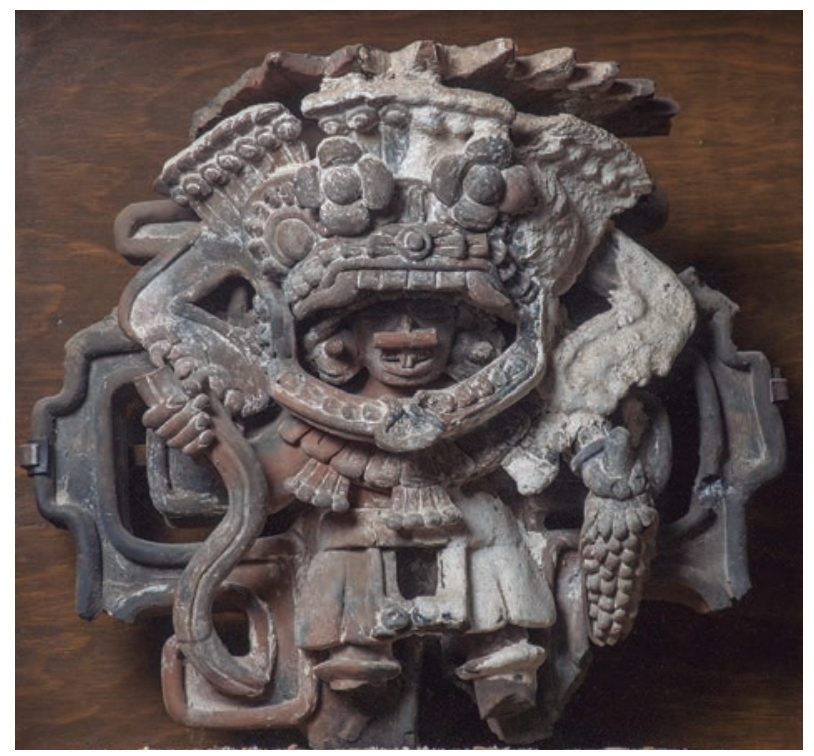

5. Cacaxtla, Once Señores, figure with jaguar headdress. Museo de Sitio de Cacaxtla. Photo: (C) Marco Antonio Pacheco. Conaculta-INAHMÉx. "Reproducción autorizada por el Instituto Nacional de Antropología e Historia."

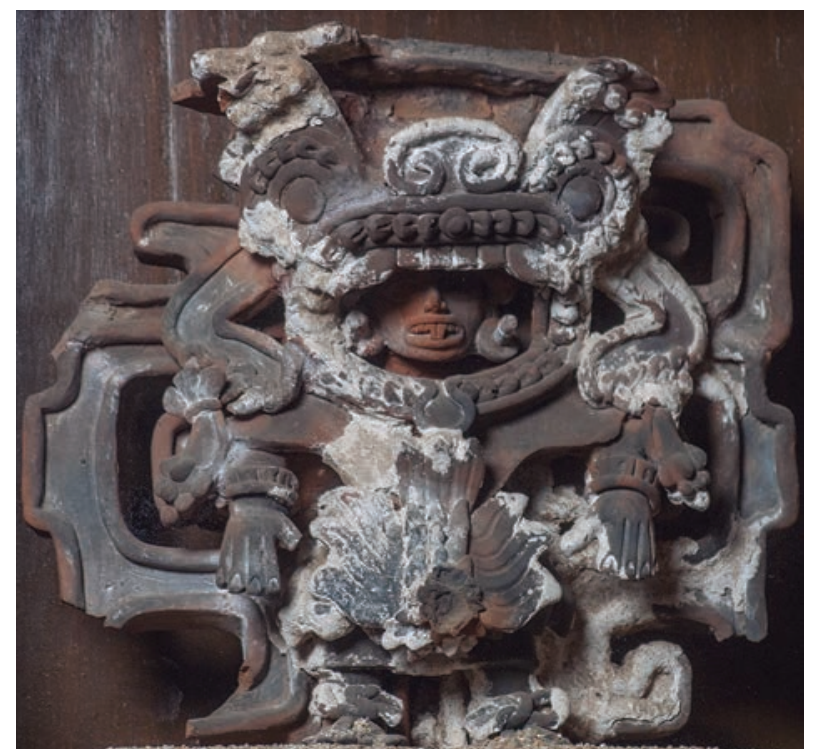

6. Cacaxtla, Once Señores, figure with jaguar headdress. Museo de Sitio de Cacaxtla. Photo: (C) Marco Antonio Pacheco. Conaculta-INAHMÉx. "Reproducción autorizada por el Instituto Nacional de Antropología e Historia." 
7. Teotihuacan, Techinantitla apartment compound. Tlaloc holding swerving lightning in one hand and maize and squash plants in the other. Taken from La pintura mural

prehispánica en México, t. I, Teotihuacán, Catálogo, t. I, Beatriz de la Fuente (coord.) (México: Universidad Nacional Autónoma de México-Instituto de Investigaciones Estéticas, I995), I32, fig. I4.2.

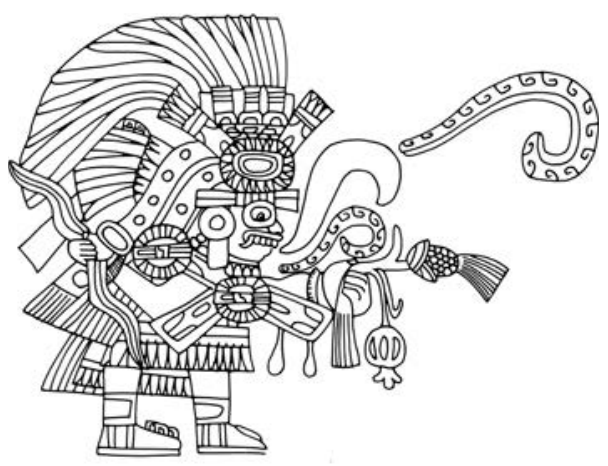

a squash-in their left. Close parallels at Teotihuacan include the processions of Tlalocs or Tlaloc impersonators carrying maize plants at the Zacuala apartment compound and the similarly-goggled figures from the Techinantitla apartment compound who bear undulating lightning staffs and ears of maize (fig. 7). ${ }^{18}$ The same iconography is repeated on stuccoed and painted tripod vases from Teotihuacan, and on more modest clay vessels with modeled Tlaloc heads and rudimentary bodies holding curving staffs. ${ }^{\text {I9 }}$

This association of Tlaloc, swerving serpent-like staffs, and water or agricultural bounty continues into the Epiclassic period. Small Tlaloc plaques from Xochicalco clutch the same objects, and although they are diminutive in scale, the jagged volutes framing these figures recall the backings of the Once Señores. ${ }^{20}$ Even closer to home, the mural of the Structure A north jamb at Cacaxtla shows a human figure, clad in a jaguar costume, grasping a serpent in one hand and pouring water out of a Tlaloc jar with the other (see fig. I). ${ }^{2 I}$ Like the four ceramic jaguar figurines, this mural recapitulates an

I8. Miller, The Mural Painting of Teotihuacan, I 2; Feathered Serpents and Flowering Trees: Reconstructing the Murals of Teotihuacan, ed. Kathleen Berrin (San Francisco and Seattle: Fine Arts Museums of San Francisco and University of Washington Press, 1988), I02; Solís, Teotihuacan: Cité des Dieux, 324-325.

19. Berrin and Pasztory, Teotihuacan: Art from the City of the Gods, cat. no. II8; Solís, Teotihuacan: Cité des Dieux, 320-322.

20. De la Fuente, Garza Tarazona et al., La Acrópolis de Xochicalco, I28-I29.

2I. Indeed, these associations are frequent at Cacaxtla. The twelfth figure resembling the Once Señores has a Tlaloc mask and a serpent-like staff (see fig. 3), while the partial urn again features this swerving staff, and another urn found at the site combines Tlaloc goggles with mold-made maize cobs (see Rivas Castro and Michetti Micó, "Iconografía y simbolismo de 
association between jaguars, Tlaloc, lightning, and agriculture, although few objects from Teotihuacan itself link jaguars into this iconographic complex. At Teotihuacan, jaguars are more likely to be associated with blood, water, and martial themes, and only rarely are connected with sowing or abundance, while the domain of the Tlaloques is tied to agricultural products like maize and squash. ${ }^{22}$

There are other divergences from the art of Teotihuacan. Most notably, one of the feline masks has four-petaled flowers in the place of the jaguar's eyes and a knotted, bow-like ornament in place of the jaguar's nose, suggesting a possible misunderstanding of the iconography involved (see fig. 5). The fourth figure, who holds his hands flat in front of his body, wears an ornament that is difficult to identify or compare to other Mesoamerican iconography (see fig. 6). Possibly a descending bird or a growing plant, this object remains enigmatic. ${ }^{23}$ Seedpods, or perhaps drops of flowing liquid, seem to fall from the claws of his jaguar headdress.

While certain key diagnostic elements-and their combination-have precedent at Teotihuacan, this particular formulation is unique to Cacaxtla. The association of jaguars, Tlaloc, and sustenance is not found at the great metropolis, but even more importantly, the Cacaxtla works seem to combine elements from different Teotihuacan media in a way that was unthinkable at the city itself. The jaguar-clad figures in the Cacaxtla ceramics have descending forelegs which are common in frontal images of jaguars at Teotihuacan but never occur on feline headdresses. Thus, the Cacaxtla headdress seems to be a conflation of a frontal feline image with a Teotihuacan-style feline headdress. ${ }^{24}$ While many other Teotihuacan-inspired works throughout Me-

los Once Señores," fig. 4.). The Battle Mural also shows the victorious jaguar-clad warriors carrying Tlaloc insignia and even a Tlaloc image into combat, see Zoltán Paulinyi, "Una imagen del dios de la lluvia en Cacaxtla y la iconografía teotihuacana," Boletín del Museo Chileno de Arte Precolombino 5 (I991): 53-66.

22. Sugiyama, "Los animales en la iconografía teotihuacana," figs. Ioo-I3 I; Hasso von Winning, Iconografía de Teotihuacán: los dioses y los signos, 2 vols. (Mexico City: Universidad Nacional Autónoma de México-Instituto de Investigaciones Estéticas, 1987), I:I00, 106. For a sixteenth century account of Tlalocs, rain, and maize, see Rafael Tena, Mitos e historias de los antiguos nahuas, 2nd ed. (Mexico City: Cien de México, 201 I), I94-197.

23. It is identified as a maguey plant by Rivas Castro and Michetti Micó, "Iconografía y simbolismo de los Once Señores," 45 I.

24. The conflation of frontal jaguar face and descending forelegs also occurs in later jaguar-serpent-bird composites at Chichen Itzá and Tula; Karl Taube identifies these images as 
soamerica seem to copy portable objects in a single medium (see below), these figures reveal a broader and perhaps deeper knowledge of Teotihuacan, one that might have required travel to the city itself to attain.

\section{Butterflies, Birds, and Bats}

The next four figures feature headdresses and costumes that combine elements of animals that fly: butterflies, birds, and bats, again with strong parallels to Teotihuacan iconography. The butterfly headdress worn by two of the figures is perhaps the most distinctive of these features (figs. 8 and 9). The curled proboscis and feathered brows are peculiarly Teotihuacan conventions, and butterflies are especially prominent in Teotihuacan art (fig. Io). Janet Berlo, Annabeth Headrick, and Karl A. Taube have discussed the iconography of these butterfly warriors as an important element of Teotihuacan militarism. ${ }^{25}$ This is one of the most common Teotihuacan motifs represented outside of Teotihuacan, as if butterfly warriors constituted an important part of the forces of Teotihuacan expansionism.

At Cacaxtla, butterfly and jaguar imagery are assimilated in a way not seen at Teotihuacan. The two figures wearing butterfly headdresses resemble

descendants of the Teotihuacan War Serpent, which, in turn, he identifies as the predecessor of the Aztec Xiuhcoatl; see Karl A. Taube, "The Turquoise Hearth: Fire, Self-Sacrifice, and the Central Mexican Cult of War," in Mesoamerica's Classic Heritage: From Teotihuacan to the Aztecs, eds. David Carrasco and Lindsay Jones (Niwot: University of Colorado Press, 2000), 28I-289. (See also Kubler, "Jaguars in the Valley of Mexico.") Taube also notes butterfly attributes in these hybrid creatures. However, the correspondence is not direct, and at Cacaxtla, these disparate creatures are not completely fused into a simple composite: although there are overlaps between the jaguar, bird, and butterfly headdresses, they are still clearly distinct entities. The substantial formal differences between the Once Señores and the later Chichen Itzá and Tula images might suggest different lines of evolution and different moments of engagement with the art of Teotihuacan.

25. Janet Catherine Berlo, "The Warrior and the Butterfly: Central Mexican Ideologies of Sacred Warfare and Teotihuacan Iconography," in Text and Image in Pre-Columbian Art: Essays on the Interrelationship of the Verbal and Visual Arts. Proceedings of the 44th International Congress of Americanists, Manchester, 1982, ed. Janet Catherine Berlo, BAR International Series I80 (Oxford: BAR, I983), 79-I I8; Annabeth Headrick, "Butterfly War at Teotihuacan," in Ancient Mesoamerican Warfare, eds. M. Kathryn Brown and Travis Stanton (Walnut Creek, CA: AltaMira Press, 2003, I49-70); The Teotihuacan Trinity: The Sociopolitical Structure of an Ancient Mesoamerican City (Austin: University of Texas Press, 2007), I24-I45; Taube, "The Turquoise Hearth" 282-285, 325-327. 

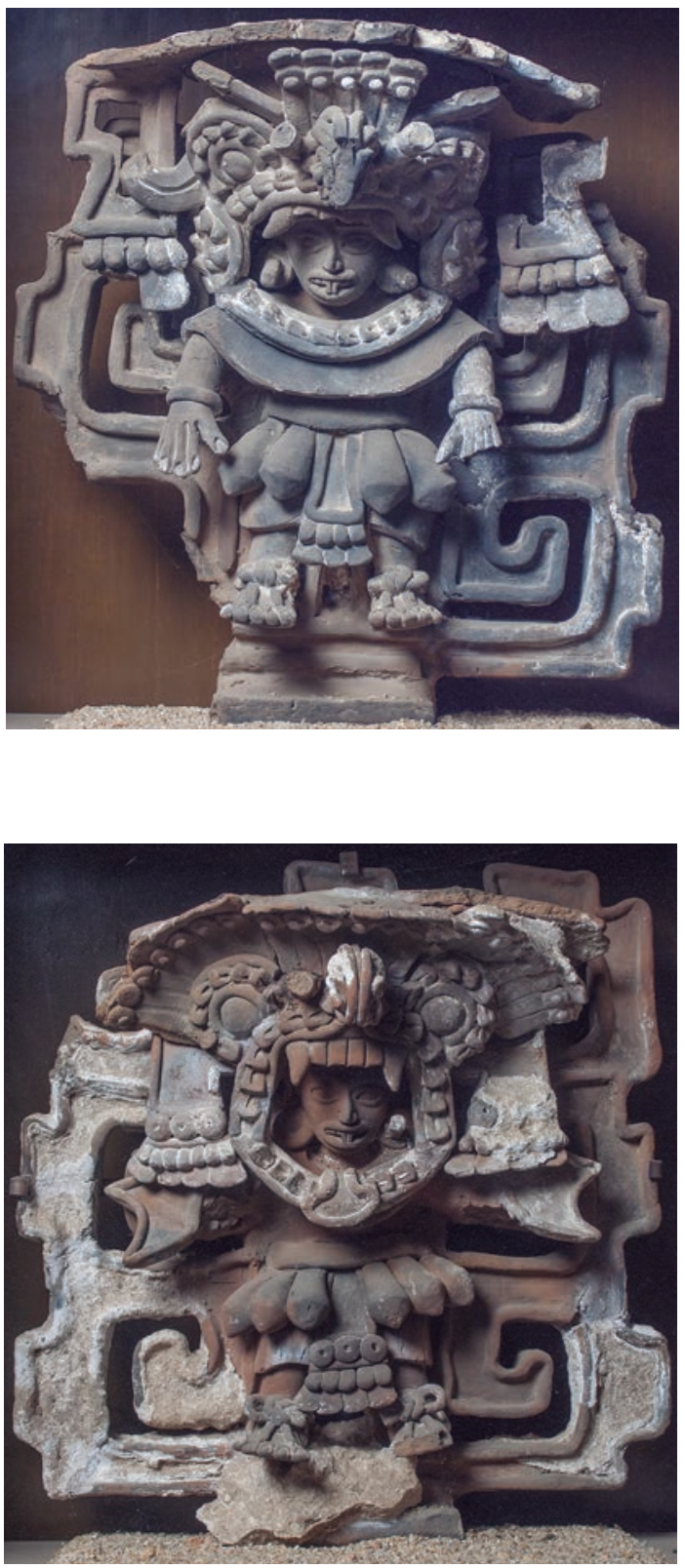

8. Cacaxtla, Once Señores, figure with butterfly headdress. Museo de Sitio de Cacaxtla. Photo: (C) Marco Antonio Pacheco. Conaculta-Inah-méx. "Reproducción autorizada por el Instituto Nacional de Antropología e Historia."
9. Cacaxtla, Once Señores, figure with butterfly headdress and bat wings. Museo de Sitio de Cacaxtla. Photo: (C) Marco Antonio Pacheco. ConacultaINAH-MÉx. "Reproducción autorizada por el Instituto Nacional de Antropología e Historia." 
Io. Teotihuacan figurine showing seated figure with butterfly headdress. Courtesy of the Peabody Museum of Archaeology and

Ethnology, Harvard University, 28-I-20/ Cioo86, file number 60742314.

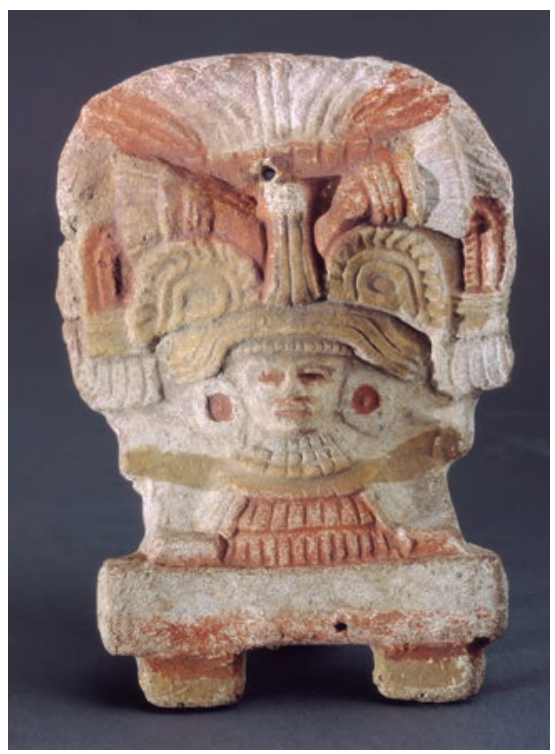

the group of figures wearing jaguar headdresses in several ways. One figure in each group extends his arms in front of the body with palms down (compare fig. 6 to fig. 8). The butterflies' feathery eyes and outcurving fangs echo the shape of the jaguar headdresses, as does the curving canopy above it. In addition, one of the butterfly headdresses has a chinstrap generally associated with jaguar headdresses (see fig. 9) and the round earrings and ornamented neck of the tunic of the other figure also echo this shape. Talud-tablero shaped vertical panels hanging from the butterfly headdresses seem to echo the descending forelegs of the jaguars, at the same time as their shape and layered, framing position seem to evoke the structure of Teotihuacan theater-type censers (see fig. 22), with emblems framing a human face, which would presumably seem to emerge from a ground of wisps of smoke if the incensario were in use.

While the formal conflation of jaguar and butterfly imagery may or may not have iconographic significance, other combinations seem likely to carry meaning. One of the pair of butterfly figures flourishes a pair of curving batlike wings (see fig. 9). This association between bats and butterflies is also found in a polychrome urn from Cacaxtla (see below), and there seems to be 
a logical relationship between these two kinds of flying creatures. ${ }^{26}$ The same is true of the combination of birds and butterflies: one of the bird headdresses at Cacaxtla seems to have a curled butterfly proboscis instead of a pointed beak (fig. I2). While the combination of bat and butterfly imagery is rare outside of Cacaxtla, birds and butterflies are frequently blended in the art of Teotihuacan and its foreign emulations (fig. II). ${ }^{27}$

The two figures with bird headdresses demonstrate other relationships to Teotihuacan art as well (figs. 12 and I3). The flaring form of these large bird headdresses, with their protruding eyes and ring-like ear ornaments, is quite unique to Cacaxtla, but birds are featured prominently at Teotihuacan, as are human figures wearing bird costumes, often warriors (fig. I4). At Cacaxtla, both figures with bird headdresses carry wide-bladed knives in their right hands (one has a long handle, while the other is short, as if the handle has broken off). ${ }^{28}$ The form of this knife may refer to the curved blades with bleeding hearts which avian warriors carry at Teotihuacan (see fig. I4), but the Cacaxtla blades bear no resemblance to excavated objects at either site, as if artists sought to represent an idea without clearly understanding its visual referent. The figure with the bird headdress carries a square bag or shield in his left hand, while the figure with the bird-butterfly headdress carries

26. Bat wings also extend above the seated figures on the clay reliefs on the north portico of Structure A, likely indicating that these scenes take place in a cave, an identification supported by the layer of painting beneath showing the convention for a cave opening, Richard F. Townsend, "Cacaxtla and Xochicalco: The Archetype of Nature's renewal," in Ideología, cosmovisión y etnicidad a través del pensamiento indigena en las Américas: 48 Congreso Internacional de Americanistas, Suecia, 1994, eds. Yosuke Kuramochi and Anna-Britta Hellbom (Quito: Abya-Yala, 1997), 98. Bats are rare in the art of Teotihuacan, but bat-headed figures do feature prominently in the art of Oaxaca. See Sue Scott, Teotihuacan Mazapan Figurines and the Xipe Totec Statue: A Link between the Basin of Mexico and the Valley of Oaxaca, Vanderbilt University Publications in Anthropology 44 (Nashville: Vanderbilt University, 1993), 26; Alfonso Caso and Ignacio Bernal, Urnas de Oaxaca. Memorias del Instituto Nacional de Antropología e Historia (Mexico City: Instituto Nacional de Antropología e Historia, 1952), 67-91. Bats are a subject of Maya art as well; see e.g., K5036, K5224 in the Maya Vase Database at http:// research.mayavase.com/kerrmaya.html.

27. Berlo, "The Warrior and the Butterfly: Central Mexican Ideologies of Sacred Warfare and Teotihuacan Iconography"; Berrin and Pasztory, Teotihuacan: Art from the City of the Gods, I26, 230, 263; Sugiyama, "Los animales en la iconografía teotihuacana," figs. 35-37.

28. Rivas Castro and Michetti Micó identify both as a kind of planting tool, "Iconografía y simbolismo de los Once Señores", 458. 
II. Teotihuacan tripod vessel with figure wearing a bird helmet with a butterfly proboscis. Fine Arts Museums of San Francisco, Bequest of Harald J. Wagner, 78.95 .

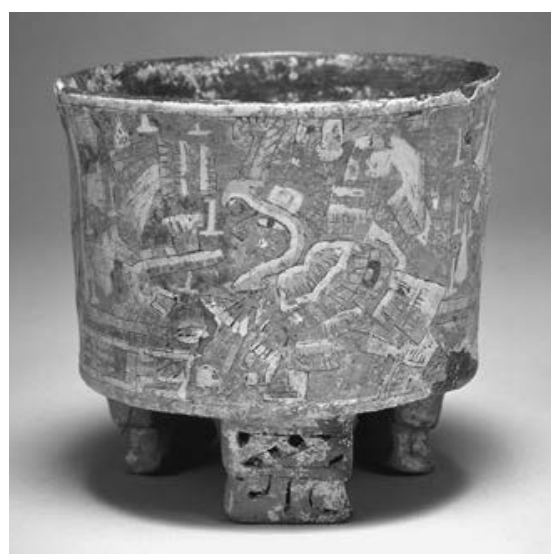

a round shield similar to an Aztec chimalli shield. ${ }^{29}$ The bird figure wears two rattlesnakes draped around its neck; the bird-butterfly figure has just a single rattlesnake, but a small feline or canine figure clings to its right arm. Both wear necklaces composed of rectangular plaques that may represent stylized footprints.

One of the most puzzling features of the bird-butterfly figure (see fig. I2) is that it appears to have two right hands, one clutching the blade, and another larger one positioned in the center of its body with an elaborate wrist cuff (the figure's left hand is presumably concealed behind the round shield). A possible explanation of this feature stems from Teotihuacan images of a bird holding a shield displaying a human hand, the lechuza y armas motif (fig. I5)..$^{\circ}$ If this is indeed the model for the Cacaxtla figure, it suggests that the Cacaxtla ceramicist was copying a Teotihuacan prototype without completely understanding its iconographic content. These shields decorated with human hands are held by anthropomorphic birds in the art of Teotihuacan, but never by human warriors in avian costume, so this misunder-

29. Both square and round shields are represented in the Battle Mural at Cacaxtla, and in the art of Teotihuacan as well (see, e.g., Berrin and Pasztory, Teotihuacan: Art from the City of the Gods, 97, 133, 247, 250.)

30. Winning, Iconografía de Teotihuacán: los dioses y los signos, I:85-90; see also Berrin and Pasztory, Teotihuacan: Art from the City of the Gods, 133, 247, 250. 

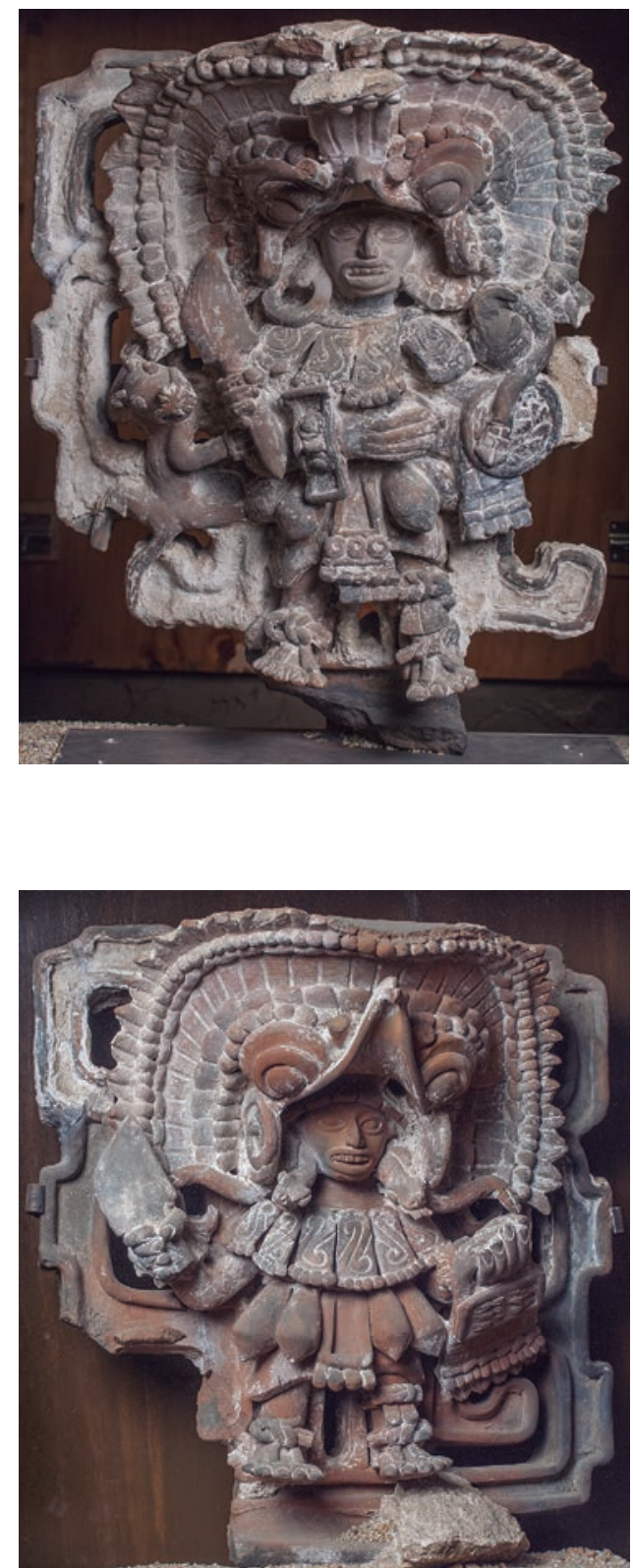

I2. Cacaxtla, Once Señores, figure with bird-butterfly headdress. Museo de Sitio de Cacaxtla. Photo: (C) Marco Antonio Pacheco. Conaculta-INAHMÉx. "Reproducción autorizada por el Instituto Nacional de Antropología e Historia."
I3. Cacaxtla, Once Señores, figure with bird headdress. Museo de Sitio de Cacaxtla. Photo: (C) Marco Antonio Pacheco. Conaculta-INAHMÉx. "Reproducción autorizada por el Instituto Nacional de Antropología e Historia." 


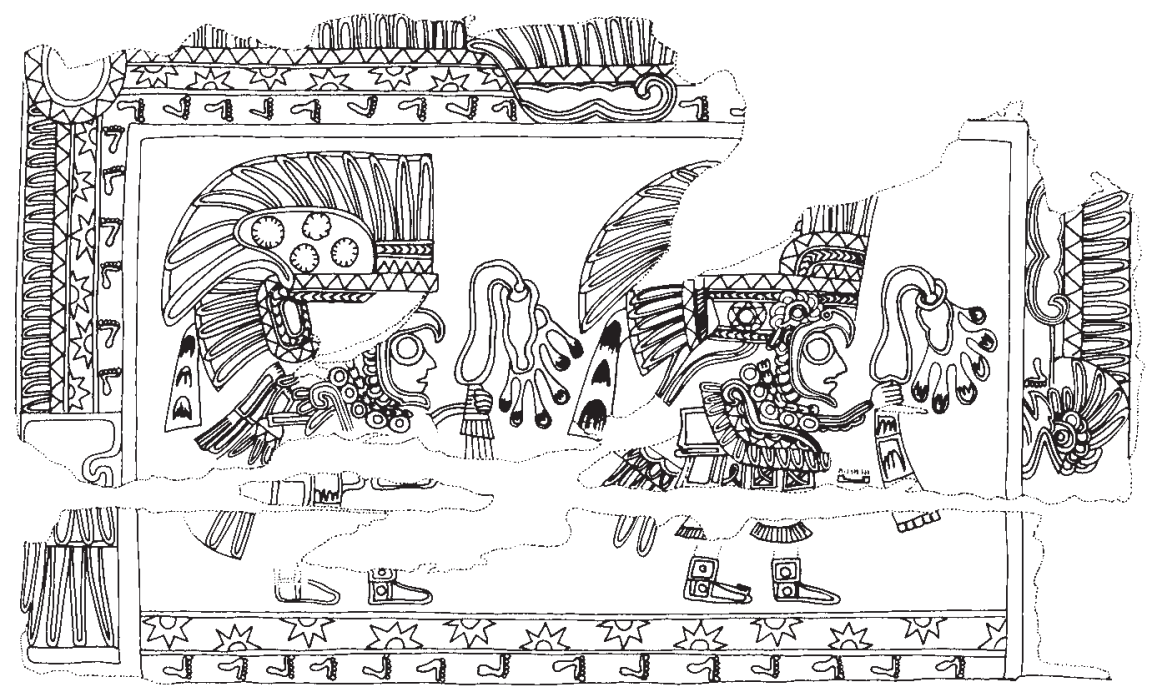

I4. Teotihuacan, Zona 5-A compound. Line drawing of warriors wearing bird costumes. Drawing by Arturo Reséndiz, after a drawing by Agustín Villagra Caleti, courtesy of the project "La pintura mural prehispánica en México," IIE, UnAm.

standing must have occurred in concert with other acts of translation from Teotihuacan prototype to Cacaxtla ceramic.

Like the four jaguar figures, this group of objects suggests a broad exposure to works of art from Teotihuacan in various media. The four bird and butterfly figures also highlight the iconographic fluidity of the Once Señores. Conflations, shared costume elements, and formal parallels link different figures into a chain of related associations, emphasizing the commonalities between birds, bats, butterflies, and jaguars. Some features, like the bird/ butterfly hybrid, have ample precedent at Teotihuacan, but others, like the repeated right hand, seem to misunderstand Teotihuacan prototypes, and still others, like the bat elements, do not even appear at Teotihuacan.

\section{Xipe Totec?}

The final three figures wear stacked, rectangular headdresses, in two cases with a small projecting knob at the top. Two of these figures, deposited as 


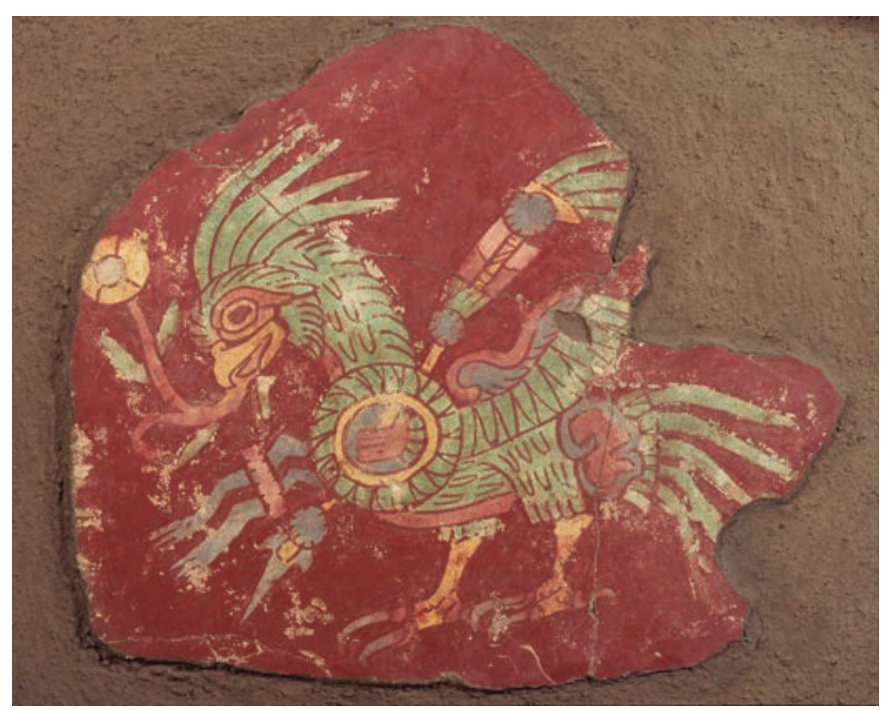

I5. Teotihuacan. Mural painting with bird holding a shield, the socalled lechuza y armas motif. Museo Nacional de Antropología e Historia. Photo: Ernesto Peńaloza, courtesy of the project "La pintura mural prehispánica en México," IIE, UnAm. Conaculta-INAH-MÉx. "Reproducción autorizada por el Instituto Nacional de Antropología e Historia."

a pair, are well-preserved, while the final figure, the only one placed alone, has suffered considerable damage (figs. I6-I8). Trilobed symbols that signify blood or some other liquid in the art of Teotihuacan and in the Cacaxtla murals hang from the headdress of one figure and the necklace and belt of another. One figure holds a leather-wrapped staff in his left hand and a fringed bag, like the ones carried by Aztec priests to hold copal incense, in his right (fig. 17). A descending jaguar with flat body and three-dimensional head alights on and grasps his right arm. The most heavily damaged figure stretches his hands in front of his body in a gesture familiar from the jaguarand butterfly-headdress figures (fig. I8), while the arms of the other figure are missing entirely (fig. I6).

The headdress differs from those worn by the other figures in its simplicity. Parallels for this type of headdress are rare in Mesoamerica, and occur in a variety of different contexts. Possible prototypes might be the broad double- 
I6. Cacaxtla, Once Señores, figure with blocky headdress. Museo de Sitio de Cacaxtla. Photo: (C) Marco Antonio Pacheco. Conaculta-INAHMÉx. "Reproducción autorizada por el Instituto Nacional de Antropología e Historia."

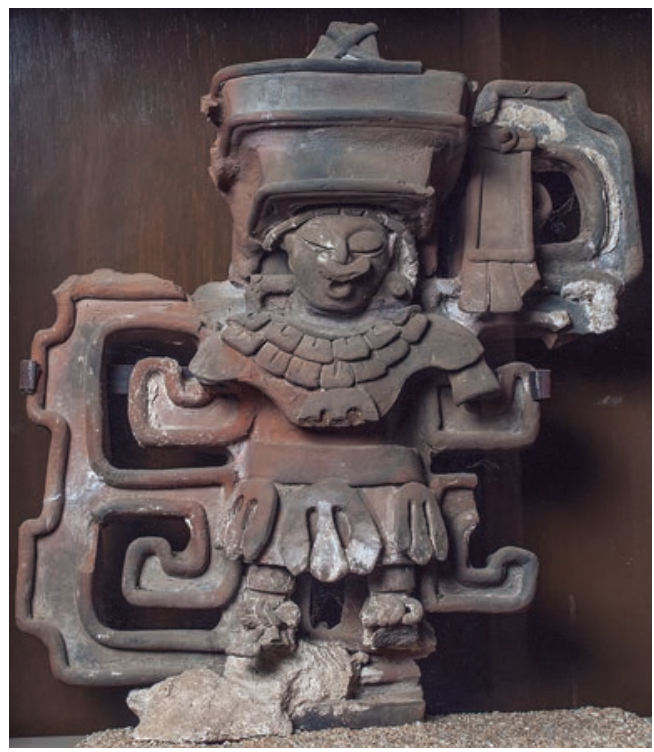

I7. Cacaxtla, Once Señores, figure with blocky headdress. Museo de Sitio de Cacaxtla. Photo: Claudia Brittenham. Conaculta-INAH-MÉX.

"Reproducción autorizada por el Instituto Nacional de Antropología e Historia."

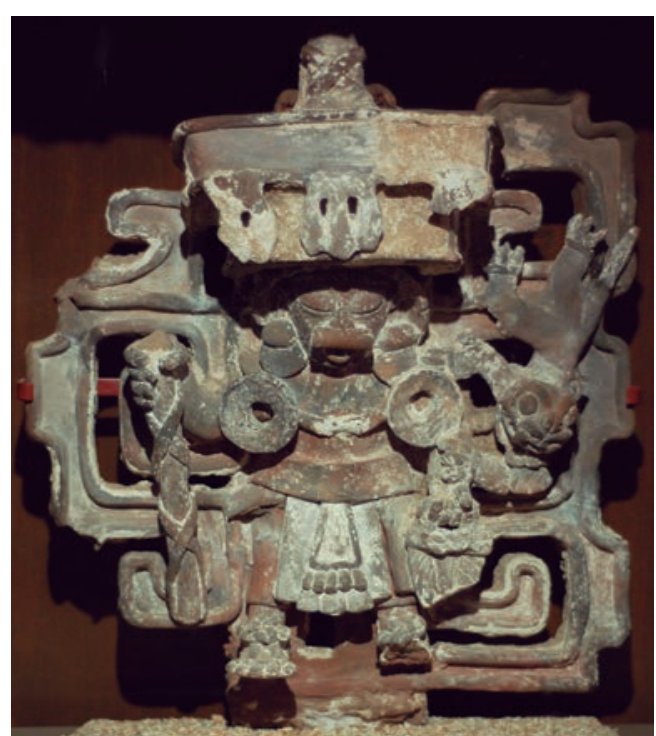




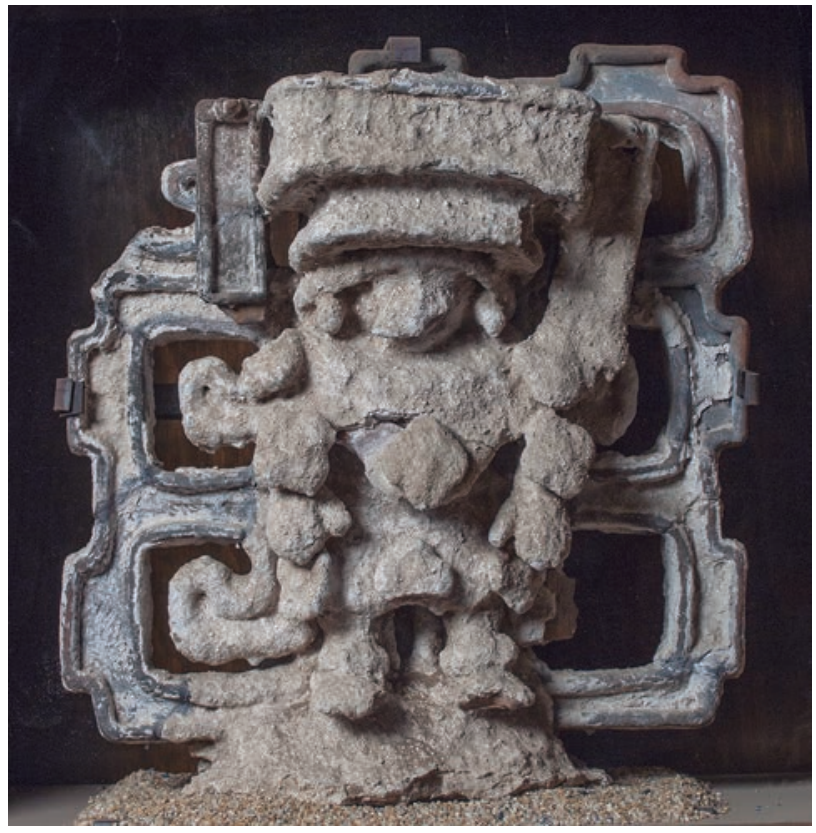

I8. Cacaxtla, Once Señores, figure with blocky headdress. Museo de Sitio de Cacaxtla. Photo: (C) Marco Antonio Pacheco. Conaculta-INAH-MÉX. "Reproducción autorizada por el Instituto Nacional de Antropología e Historia."

horizontal band headdress on the unusual incensario cover excavated by Linda Manzanilla at Oztoyahualco, Teotihuacan..$^{3 \mathrm{I}}$ This thick banded structure echoes the two horizontal plaques generally covered with adornos above the face in theater-type censers, suggesting a surface upon which to add details. Another visual similarity may be found in the blocky headdresses worn by monumental ceramic goddesses from El Zapotal. ${ }^{32}$

31. See Linda Manzanilla and Emilie Carreón, "A Teotihuacan Censer in a Residential Context, an Interpretation," in Ancient Mesoamerica 22, no. 2 (I99I): 299-307; Berrin and Pasztory, Teotihuacan: Art from the City of the Gods, 97.

32. See Nelly Gutiérrez Solana and Susan K. Hamilton, Las esculturas en terracota de El Zapotal, Veracruz, Cuadernos de Historia del Arte 6 (Mexico City: Universidad Nacional Autónoma de México-Instituto de Investigaciones Estéticas, 1977), figs. 5, 6. 
However, what is most distinctive about this group are their faces, with crescent-shaped eyeslits and mouths rounded into an o-shape. These features suggest that the figures may be wearing flayed skin masks, characteristically associated with the deity that the Aztecs called Xipe Totec, "our lord of the flayed skin." 33 Postclassic images of this deity (or his impersonators) commonly wear flayed skin masks with similar emphasis on the mouth and eye holes, but these figures typically wear full-body flayed skin costumes, which the Cacaxtla figures do not seem to do.

Unlike the ceramics discussed so far, the closest parallels for these three figures are to be found not at Classic period Teotihuacan, but at scattered Epiclassic and Early Postclassic sites, in several large ceramic figures that seem to wear highly-textured versions of the flayed-skin suit worn by the Postclassic Xipe Totec. The first of these figures was found by Sigvald Linné in a Mazapa (Early Postclassic) context at the Xolalpan compound at Teotihuacan (fig. 19); subsequent figures have been recovered from Coatlinchan near Texcoco and San Mateo Tezoquipan near Chalco, both in Central Mexico, and at Chalchuapa in El Salvador. ${ }^{34}$ Freestanding sculptures in the round, measuring between I and 3 meters in height, these ceramics dwarf the Once Señores and clearly served a different function, but all have in common the crescent-shaped eyes, closed to slits, and the rounded, protruding mouth. ${ }^{35}$ The Xolalpan figure also wears a prominent nose ornament, like the figures

33. Carlos Javier González González, Xipe Tótec: Guerra y regeneración del maiz en la religión mexica (Mexico City: Instituto Nacional de Antropología e Historia and Fondo de Cultura Económica, 2011); Henry B. Nicholson, "The Cult of Xipe Totec in Mesoamerica," in Religión en Mesoamérica: XII Mesa Redonda de la Sociedad Mexicana de Antropología, eds. Jaime Litvak King and Noemí Castillo Tejero (Mexico City: Sociedad Mexicana de Antropología, 1973), 213-2I8; Anne-Marie Vié-Wohrer, Xipe Totec: Notre seigneur l'écorché: étude glyphique d'un dieu Aztèque (Mexico City: Centre d'Études Mexicaines et Centroaméricaines, 1999).

34. Sigvald Linné, Archaeological Researches at Teotihuacan, Mexico, The Ethnographical Museum of Sweden New Series, Publication No. I (Stockholm: The Ethnographical Museum of Sweden, 1934), 83-84; Stanley Boggs, "A Human-Effigy Pottery Figure from Chalchuapa," Carnegie Institution of Washington Notes on Middle American Archaeology and Ethnology 2, no. 3I (1944); González González, Xipe Tótec, 59-68; Marshall H. Saville, "An Ancient Figure of Terra Cotta from the Valley of Mexico," Bulletin of the American Museum of Natural History, 9 (1897), 22 I-224; Scott, Teotihuacan Mazapan Figurines and the Xipe Totec Statue, 25-5I.

35. Another formal parallel may be found in the monumental terracotta female deities from El Zapotal with their eye slits and o-shaped mouth, although the similarities seem to end there. See Gutiérrez Solana and Hamilton, Las esculturas en terracota de El Zapotal, Veracruz, figs. 2, 5, 6, 60, 62 . 


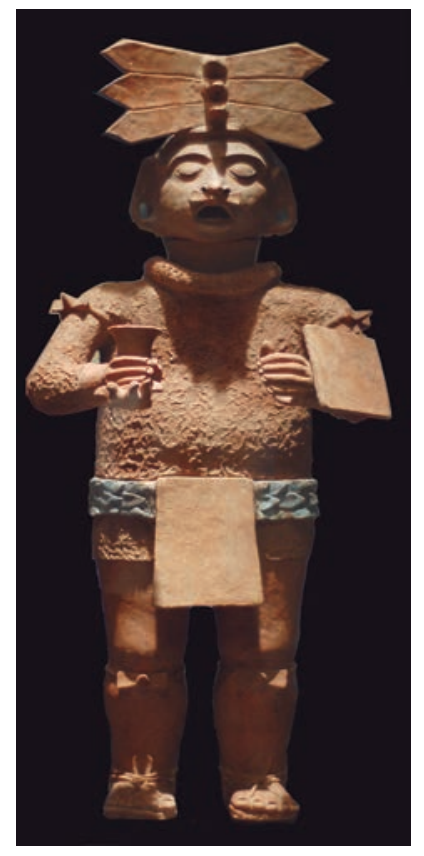

19. Xipe Totec from Xolalpan, Teotihuacan. Epiclassic. Museo Nacional de Antropología. Photo: Claudia Brittenham. Conaculta-INAH-MÉx. "Reproducción autorizada por el Instituto Nacional de Antropología e Historia."

among the Once Señores. In its right hand, the Xolalpan statue carries a kind of bat-claw ceramic vessel known from Oaxaca, evidence of an interconnected Mesoamerican world; the jaguar wearing a knotted neckcloth on the best-preserved Cacaxtla Xipe figure (fig. I7) also points towards Oaxaca, although it also appears at Xochicalco and in the Maya region. ${ }^{6}$

The presence of Xipe Totec imagery at Teotihuacan remains hotly debated. A group of figures wearing masks with rounded eyes and mouth holes has sometimes been associated with Xipe (fig. 20), but this association has also frequently been questioned. ${ }^{37}$ Recently, Karl A. Taube and Marc Uwe

36. For the Xolalpan figure, see Scott, Teotihuacan Mazapan Figurines and the Xipe Totec Statue, 26-31. For Oaxaca jaguars, see, e.g., Caso and Bernal, Urnas de Oaxaca, 57. For similar creatures at Xochicalco, see De la Fuente, Garza Tarazona et al., La Acrópolis de Xochicalco, 23, I3I. Maya jaguars with neckcloths may be found in the Maya Vase Database at http:// research.mayavase.com/kerrmaya.html (e.g., KII52, KI230).

37. For the Xipe interpretation, see Laurette Séjourné, Un palacio en la ciudad de los dioses (Mexico City: Instituto Nacional de Antropología e Historia, 1959), 22, 97, 99; Eduard Seler, 


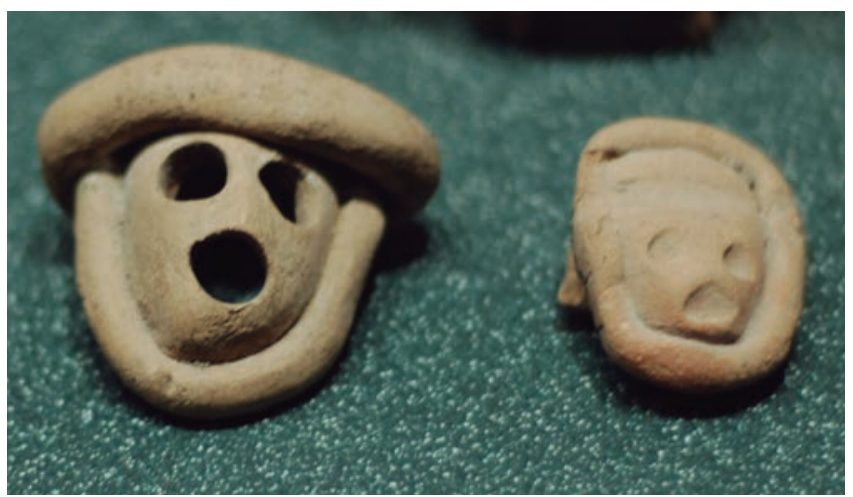

20. Teotihuacan ceramic figurine heads which have been identified as Xipe Totec or as boxers. Museo Nacional de Antropología. Photo: Claudia Brittenham. Conaculta-INAH-MÉx. "Reproducción autorizada por el Instituto Nacional de Antropología e Historia.”

Zender have argued that these figures are instead masked boxers, citing the headband and chinstrap that accompany the mask, as well as the padded arm and leg bands and diagonal bandolier that occur with it, as elements of a kind of costume worn for ritual hand-to-hand combat throughout Mesoamerica. ${ }^{8}$ Taube and Zender suggest that a more likely candidate for a Xipe Totec antecedent at Teotihuacan are figures with vertical stripes on their faces, such

\footnotetext{
"Similarity of Design of Some Teotihuacan Frescoes and Certain Mexican Pottery Objects," Proceedings of the International Congress of Americanists (I8th session, London, I9I2) I (I9I3): 196. For skepticism about this identification, see e.g., Scott, Teotihuacan Mazapan Figurines and the Xipe Totec Statue, 45-51; Winning, Iconografia de Teotihuacan: los dioses y los signos, I:I $47-150$.

38. Karl A. Taube and Marc Uwe Zender, "American Gladiators: Ritual Boxing in Ancient Mesoamerica," in Blood and Beauty: Organized Violence in the Art and Archaeology of Mesoamerica and Central America, eds. Rex Koontz and Heather Orr (Los Angeles: UClA Cotsen Institute of Archaeology, 2009), I7I-I74. If this is the case, the confusion caused by the similarity between the form of the masks may stem from the fact that boxers likely wore animal skin masks with prominent eye holes, like those attested in contemporary ceremonial boxing costume in Mexico. Boxers are especially common in the Epiclassic art of Santa Lucía Cotzumalhuapa, and these distant images help elucidate the imagery of Teotihuacan, see Taube and Zender, "American Gladiators," I73-I74, fig. 7.I; Oswaldo Chinchilla Mazariegos, "Games, Courts, and Players at Cotzumalhuapa, Guatemala," I54-I57.
} 
as the wall painting in the Zacuala apartment compound (fig. $2 \mathrm{I}$ ), or the recently discovered greenstone figure from the Xalla compound. ${ }^{39}$ No facial stripes can be discerned on the Cacaxtla figures, but the crescent-shaped form of their nearly-closed eyes is very similar to the Zacuala mural, and additionally provides a link to the other Epiclassic-Early Postclassic figures, some of which do display the vertical facial stripes.

These three figures have the most tenuous ties to the art of Teotihuacan, or anywhere else in Mesoamerica, for that matter. Their most diagnostic features, the crescent-shaped slit eyes and the rounded mouth holes, suggest a link to images of Xipe Totec ranging from Teotihuacan to the Aztecs, with the closest parallels in a diverse group of roughly contemporary clay sculptures. Seemingly a distinctive local variation on a pan-Mesoamerican deity, they highlight the degree to which religious iconography was in flux during the Epiclassic period.

\section{Teotihuacan and Cacaxtla: Prototype and Transformation}

These eleven figures from Cacaxtla constitute a distinctive and cohesive corpus. None could be mistaken for an object from Teotihuacan, but all display a degree of knowledge of Teotihuacan art and religion, evident in both iconography and formal character. If they were indeed almenas, the Once Señores offer a different approach to this form of architectural ornament, which at Teotihuacan tended to be flat figural plaques or geometric shapes..$^{4}$ In contrast, the accretive format and the bold layering of space in the Once Señores recall Teotihuacan theater-type incensarios, where a human face is partially obscured by accoutrements added around and on top of it (fig. 22).

39. Séjourné, Un palacio en la ciudad de los dioses, 22, fig. 26; Leonardo López Luján, Laura Filloy Nadal et al., "The Destruction of Images in Teotihuacan: Anthropomorphic Sculpture, Elite Cults and the End of a Civilization," RES 49/50 (2006): 26-27; Karl A. Taube, The Major Gods of Ancient Yucatan, Studies in Pre-Columbian Art and Archaeology 32 (Washington, D.C.: Dumbarton Oaks Research Library and Collection, I992a), I07-I I I. For a cautionary note, see Henry B. Nicholson, "Preclassic Mesoamerican Iconography from the Perspective of the Postclassic: Problems in Interpretational Analysis," in The Origins of Religious Art and Iconography in Mesoamerica, ed. Henry B. Nicholson (Los Angeles: University of CaliforniaLatin American Center, I976), I64-I67.

40. Taube, "Tetitla and the Maya Presence at Teotihuacan," 274-275; Berrin and Pasztory, Teotihuacan: Art from the City of the Gods, I73, 208. 
2I. Teotihuacan, Zacuala apartment compound. Mural painting with attributes

of Xipe Totec. Line drawing by Karl A.

Taube.

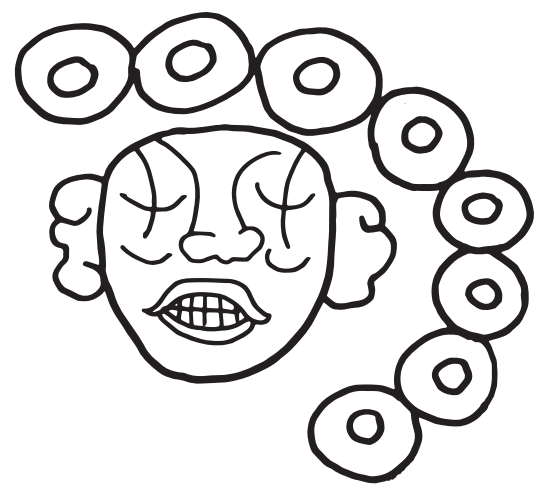

Mold-made plaques representing butterflies, birds, feathered shields, shells, and other forms generally framed a central mask as if to form its headdress and accoutrements, but on closer examination, as in so many of the Teotihuacan murals, with rare exception, no body is to be found. ${ }^{4}$ The patently two-dimensional representations of Teotihuacan are given three-dimensional volume in the Cacaxtla images, distinguishing them unequivocally from their flat, schematic prototypes. It moves them away from the realm of abstracted conventions to corporeal existence in space, closer to the human dimension, as if the insignia were brought to life on the human frame and given new vitality and significance.

One of the most important departures from Teotihuacan prototypes is this corporality of the figures at Cacaxtla. While butterfly and jaguar headdresses at Teotihuacan often top disembodied busts, real bodies wear these headdresses at Cacaxtla. These are costumes, not attributes. Whether deities, deity impersonators, priests, or ancestors, these beings seem to be portrayed as essentially human. While the four figures with jaguar headdresses among the Once Señores have Tlaloc faces, on the twelfth figure recovered near Cacaxtla (see fig. 3), the Tlaloc mask parts to reveal the human wearer, the human actor intervening in petition to the gods.

4I. One notable exception to this pattern is the theater-type censer excavated by Linda Manzanilla at the Oztoyahualco apartment compound at Teotihuacan, which shows a standing figure with elaborate headdress holding rectangular shields in both hands; with the whole body visible; see Manzanilla and Carreón, "A Teotihuacan Censer." 


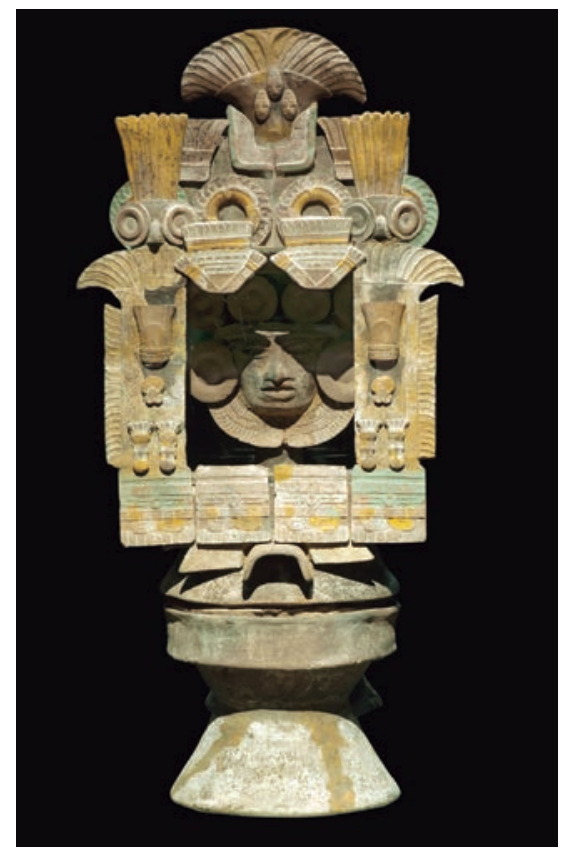

22. Teotihuacan theater-type censer. Museo Nacional de Antropología. Photo: Ricardo Alvarado, courtesy of the project "La pintura mural prehispánica en México," IIE, UnAm. Conaculta-INAH-MÉx. "Reproducción autorizada por el Instituto Nacional de Antropología e Historia."

This "personification" of Teotihuacan-style iconography is common throughout Mesoamerica. Artists in other regions might adopt iconographic elements from Teotihuacan, but they resisted the anonymous, disembodied, and abstract stylistic qualities of its art-and possibly some of the beliefs that accompanied it. Some of the closest conceptual parallels for the Cacaxtla ceramics are incensarios from Escuintla, Guatemala, which Janet Catherine Berlo has discussed as an example of "provincial" Teotihuacan art. ${ }^{42}$ Like the Cacaxtla figures, these incensarios undergo a process of embodiment, where the addition of hands and changes in the backdrop transform them from the masklike dioramas of Teotihuacan into busts of human warriors (fig. 23). ${ }^{43}$ Several of these incensarios show the same butterfly headdress worn at Cacaxtla.

42. Janet Catherine Berlo, Teotihuacan Art Abroad: A Study of Metropolitan Style and Provincial Transformation in Incensario Workshops, BAR International Series I99 (Oxford: BAR, I984).

43. For the context of this object, see Berlo, Teotihuacan Art Abroad, 80-8I; Frederick Bove and Sonia Medrano Busto, "Teotihuacan, Militarism, and Pacific Guatemala," in The Maya and Teotihuacan: Reinterpreting Early Classic Interaction, ed. Geoffrey Braswell (Austin: Uni- 
23. Teotihuacan-style incensario excavated at El Manantial, Escuintla, Guatemala. Photo: Maynor Marino Mijangos. (C) 2009, GalasdeGuatemala.com

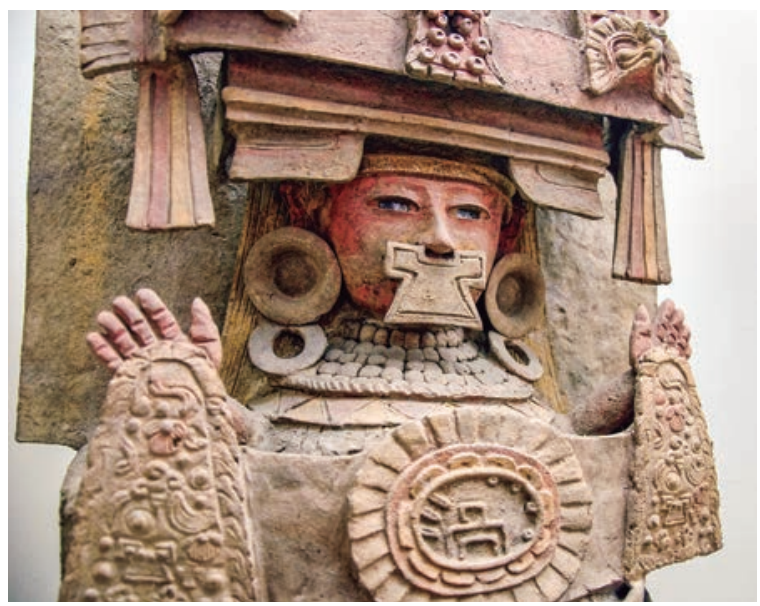

The same class of Teotihuacan incensarios may also have inspired the makers of ceramic urns found in Zapotec tombs at Monte Albán and elsewhere in Oaxaca. Building on a long-standing tradition, Zapotec urns acquired a new, intensely accretive character and iconographic density at the moment of maximal contact with Teotihuacan. Teotihuacan-style butterfly headdresses are also borrowed into the iconographic repertory of Zapotec urns, where they display a similar aesthetic of accretion. ${ }^{44}$ But once again, these attributes are attached to robustly human bodies as they are integrated into Zapotec tradition.

Matthew Robb has noted a similar process of personification in images of Huehueteotl outside of Teotihuacan, as this characteristically Teotihuacan deity is reinterpreted in local stylistic idioms (personal communication, 2007). At Teotihuacan, the old god bows heavily beneath the brazier resting on his head, his body rendered as a few abstract planes curving away from the viewer, a dark void between the wrinkled face and crossed legs. But outside of Teotihuacan, in a ceramic figure from Cerro de las Mesas on the Gulf Coast,

versity of Texas Press, 2003), 56-63; Sonia Medrano Busto, "Un incensario estilo teotihuacano de Escuintla," in VII Simposio de Investigaciones Arqueológicas en Guatemala, I993, eds. Juan Pedro Laporte and Héctor L. Escobedo (Guatemala: Museo Nacional de Arqueología y Etnología, 1994), I07-I I7.

44. See e.g., Caso and Bernal, Urnas de Oaxaca, 34I-343, fig. 507. 
for example, the wrinkled face, cross-legged posture, and heavy brazier are repeated, but attention is lavished on the old god's body, detailing his sagging breasts and the roll of fat on his belly. And an Aztec example, centuries later, similarly rejects Teotihuacan abstraction to more fully specify the body beneath. 45

Especially significant are the differences in production technology. While Teotihuacan objects are often mold-made in mass quantities, ${ }^{46}$ the Cacaxtla Once Señores combine hand-modeled and mold-made elements, most notably the faces of the bird/butterfly group. Yet no two are precisely alike, as if a separate mold were made to make each of the faces. Could technology - the use of molds - here be a citation of Teotihuacan technology, as important as style or iconography in associating these objects with the great metropolis? Escuintla incensarios and Zapotec urns also display novel uses of mold-making technologies in their respective regions, although of course $\mathrm{Za}$ potec ceramics are occasionally replicated in sets for which the use of a mold is a logical application. Recently, Mary Miller has also argued that the use of molds to make Maya figurines, such as those most commonly associated with Jaina Island, also has its inspiration in Teotihuacan technology (personal communication, 2012). What is important here is the possibility that technological style, ${ }^{47}$ as well as the more traditional art historical categories of iconography and formal style, could be an important form of emulation.

Despite their connections to Teotihuacan roots, these objects could never be confused with ceramics from the great metropolis. They were not made by Teotihuacan-trained artists, nor by directly copying a Teotihuacan prototype. Instead, it seems that the Once Señores, like much of the other elite material

45. Eduardo Matos Moctezuma and Felipe Solís Olguín, Aztecs (London: Royal Academy of Arts, 2002), cat. no. 229.

46. Molds began to be used at Teotihuacan in the Late Tlamimilolpa or early Xolalpan phases (ca. A.D. 350-500), perhaps providing comparative evidence to help date these figures. See Warren Barbour, "The Figurine Chronology of Teotihuacan, Mexico," in Los ritmos de cambio en Teotihuacán: reflexiones y discusiones de su cronología, eds. Rosa Brambila and Rubén Cabrera Castro, Colección Científica, Serie Arqueología (Mexico City: Instituto Nacional de Antropología e Historia, 1988), 243-253; Janet Catherine Berlo, "Artistic Specialization at Teotihuacan: The Ceramic Incense Burner," in Pre-Columbian Art History: Selected Readings, ed. Alana Cordy-Collins (Palo Alto: Peek Publications), I982, 83-Ioo.

47. The term is from Heather Lechtman, "Style in Technology-Some Early Thoughts," in Material Culture: Styles, Organization, and Dynamics of Technology, eds. Heather Lechtman and R. S. Merrill (St. Paul: American Ethnological Society, 1977), 3-20. 
culture produced at Cacaxtla, are very much a local product reformulated in a local idiom. The rather free blending of traits in the Once Señores suggests a lack of strict canons governing the use and combination of elements in these images perhaps derived from the lack of rigid state controls or possibly from a different understanding of Teotihuacan ideas. How can these different approaches to Teotihuacan ideas be interpreted: Did they result from a lack of understanding on the part of outsiders approaching Teotihuacan iconography or a deliberate decision to modify it? Might they indicate a disjunction between the date of the Once Señores and their Teotihuacan models?

\section{The Once Señores at Cacaxtla}

What is also striking about the Once Señores is how different they are from the Cacaxtla murals and other works of art contemporary to the paintings, especially in the relationship that they display to the art of Teotihuacan. No other works of art from Cacaxtla, whether murals, unbaked clay sculpture, ceramic figurines, or polychrome urns, display as close formal and iconographic ties to Teotihuacan as this group of objects. However, there are some points of intersection, which demonstrate continuity between the Once Señores and other Cacaxtla traditions.

Motifs familiar from Teotihuacan provide the framework of the Cacaxtla paintings: the aquatic borders, feathered serpents, and pointed stars have clear predecessors at Teotihuacan, although their presentation at Cacaxtla is inflected with Maya naturalism. ${ }^{4}$ The pictorial writing system used in the Cacaxtla murals and later Central Mexican books may also have its origins at Teotihuacan. ${ }^{49}$ The way that the Cacaxtla murals are often structured in terms of binary oppositions, which resolve into greater wholes, is also reminiscent of much Central Mexican tradition, both before and after. ${ }^{50}$ Yet the

48. Abascal, Dávila et al., "La arqueología del sur-oeste de Tlaxcala (primera parte)," 33; Donald McVicker, “The 'Mayanized Mexicans', American Antiquity 50, no. I (I985): 91.

49. Janet Catherine Berlo, "Early Writing in Central Mexico: In Tlilli, In Tlapalli before A.D. I00o," in Mesoamerica After the Decline of Teotihuacan, 20-23; George L. Cowgill, "Teotihuacan Glyphs and Imagery in the Light of Some Early Colonial Texts," in Art, Ideology, and the City of Teotihuacan, ed. Janet Catherine Berlo (Washington, D.C.: Dumbarton Oaks Research Library and Collection, 1992), 231; Karl A. Taube, The Writing System of Ancient Teotihuacan (Washington, D.C.: Center for Ancient American Studies, 2000).

50. Michel Graulich, "Dualities in Cacaxtla," in Mesoamerican Dualism/Dualismo Meso- 
style of these murals, with its clear Maya antecedents, and their many Maya or more broadly pan-Mesoamerican themes, can mask the degree of Central Mexican continuity in the paintings. Indeed, the Maya-like style of the murals may even have been intended as a public repudiation of Teotihuacan, a city already in collapse by the time the murals were painted. ${ }^{\text {I }}$

At the same time, just as the Once Señores do not merely replicate Teotihuacan ideas, the Cacaxtla murals adapt Maya painting traditions. As Sonia Lombardo de Ruiz puts it, "the painters of Cacaxtla used elements of Maya tradition, but they did not repeat them mechanically, instead, they selected and recombined them to create their own language." 52 The evaluative criteria underlying the Cacaxtla paintings are distinct from contemporary Maya standards, preferring legibility and uniformity to the more ornate and calligraphic aesthetics prevalent among the Maya city-states. ${ }^{53}$

There are some continuities between the iconography of the Once Señores and the murals of Cacaxtla. Both prominently feature birds and, even more specifically, associate jaguars, Tlaloc, and lightning staffs (see above). Themes of warfare and fertility receive emphasis in both the paintings and the ceramics. But the style in which these themes are rendered is strikingly different, far more than mere differences in media can explain. The bird and jaguar costumes in the murals of the Battle Mural and Structure A are rendered in naturalistic form, like the costumes of Maya masquerades or El Tajín ritual performances, rather than in the conventionalized Teotihuacan idiom of the Once Señores (compare fig. I to fig. 2). The Once Señores are squat, with disproportionate emphasis on the head, like figures in the art of Teotihuacan but unlike the elongated figures of the murals, which more closely approximate human proportions. Equally striking are the places where there is little overlap between murals and the Once Señores: two of the most insistent themes in this corpus, the butterfly headdress figures and the Xipe Totec figures with

americano: Symposium of the 46th International Congress of Americanists, Amsterdam, 1988, eds. Rudolf van Zantwijk, Rob de Ridder et al. (Utrecht: RUU-ISOR, I990), 94-I I8; Brittenham, The Murals of Cacaxtla, 197-20I.

51. See Claudia Brittenham, "Style and Substance, or Why the Cacaxtla Paintings Were Buried," Res 55/56 (2009): I35-I55; The Murals of Cacaxtla, 26-44.

52. Sonia Lombardo de Ruiz, "Las pinturas de Cacaxtla," Arqueología Mexicana 3, no. I3 (1995): 34, our translation.

53. For further discussion, see Brittenham, The Murals of Cacaxtla. 
their tiered headdresses and flayed skin masks, have no commonality with the themes of the surviving murals.

\section{Other Cacaxtla Ceramics}

Even more striking are the stylistic and iconographic divergences between the Once Señores and other ceramics found at the Cacaxtla-Xochitécatl-Nativitas block. Ceramics as large and elaborate as the Once Señores were rarely found during excavations at Cacaxtla, because most of the spaces of the acropolis were swept clean before being renovated. Construction fill for new buildings did contain ceramic fragments, but rarely complete objects. ${ }^{54}$ Still, neither the few surviving examples of large-scale fired polychrome objects or unfired clay sculpture nor the smaller figurines so common at Xochitécatl have much in common with this group of figures. ${ }^{55}$ Unfired clay sculptures recovered from Cacaxtla were much larger than the Once Señores, more closely approximating, in their nearly-human scale and their naturalistic proportions, the appearance of the Cacaxtla murals (fig. 24). The wrinkles on one aged face, or the swelling paunch of the one nearly complete figure, who wears a simple plated collar and hipcloth like many of the figures on the Battle $\mathrm{Mu}-$ ral, suggest a distinct tradition more closely tied to the murals' naturalism. Likewise, the polychrome ear of corn or the coiled serpent tail found in the Patio Hundido, now in the Museo de Sitio de Cacaxtla, similarly demonstrate a closer relationship to the murals in terms of subject, scale, coloration, and naturalism.

Two polychrome urns deposited in successive renovations of the Great Plaza offer the closest parallels in terms of scale, iconography, and accretive approach, but they also highlight the distance between the Once Señores

54. López de Molina and Molina Feal, “Arqueología,” 20, 43-46, 66-70.

55. There is little connection between the Once Señores and the abundant and highly diverse terracotta material found at the neighboring hill of Xochitécatl. Much of the Xochitécatl material consists of female figurines, standing, sitting, or with babies, which also contrast sharply in scale, style, and iconography with the Once Señores. Fragments of the kind of female figurines found at Xochitécatl were also recovered on the Cacaxtla acropolis, as were a number of fragments of male figurines, hand modeled, dressed in simple loincloths with depressions in their chests, possibly for the insertion of some kind of offering (López de Molina and Molina Feal, "Arqueología", 20, 66-68, figs. I37-I45). All of these figurines were much smaller in scale than the Once Señores, and do not show the same kind of accretive modeling or iconographic complexity as the larger figures. 


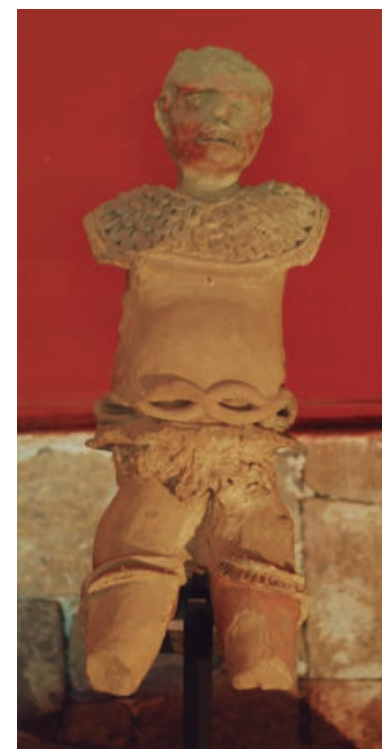

24. Cacaxtla, unfired clay figure found during roof excavations. Museo de Sitio de Cacaxtla. Photo: Claudia Brittenham. Conaculta-INaH-MÉx. "Reproducción autorizada por el Instituto Nacional de Antropología e Historia."

and the Cacaxtla murals. In style and content, the urns are much closer to the murals, and the archaeological context allows them to be linked closely to the moment when the murals were painted. The two urns are very similar in format and decoration. ${ }^{56}$ Each has an annular base and straight, sloping sides, topped with a lid with a flower for the handle. Both urns are nearly 40 $\mathrm{cm}$ tall, including the lid, and approximately $25 \mathrm{~cm}$ in diameter at the mouth, and feature a central, frontal figure wearing a face-engulfing helmet, flanked on both sides by cacao plants and attendant figures. The earlier of the two urns features a central figure with jaguar-spotted wings and a headdress with a curving butterfly proboscis, while the later of the two features a central figure wearing a bird helmet and blue-green feathers as his wings (fig. 25). The attendants are simply dressed in white loincloths and necklaces with a single pendant. They sport unusual tufted hairstyles, and several appear to be physically deformed.

Both urns were recovered during excavations of the Great Plaza at the Cacaxtla acropolis, and they can thus be linked both spatially and stratigraphically to the Cacaxtla murals. Apparently deposited as offerings during

56. Delgadillo Torres, "Las urnas policromadas de Cacaxtla, Tlax. (estudio preliminar)." 
successive renovations of the Great Plaza, they also have a clear chronological relationship to one another. The earlier urn featured the central figure with jaguar-spotted wings and a butterfly headdress (fig. 26).57 Found 3.5 meters below the level of the Great Plaza, it necessarily predated the construction of the Great Plaza and the paintings surrounding it (that is, the Battle Mural, Structure A, and the Red Temple stair).$^{5}$ Because of its great depth, it may also be substantially earlier than all of the Cacaxtla paintings excavated to date. 59 By contrast, the other urn is tightly related to the moment when the Battle Mural, Structure A, and Red Temple paintings were created. It may have been deposited slightly before the portico and jamb murals of Structure A were painted, likely in the early to mid-ninth century. ${ }^{60}$

57. This urn was found in 1985 during a study of soil mechanics in preparation for the construction of the roof that now covers the site. A test pit was dug in front of the staircase which leads from the Great Plaza to the Palace to the south, which continued down 4 meters without exhausting the fill. The urn was not found directly in this pit, but after a heavy rainfall, it washed out of the soil directly to the north of the test pit, from a level about 3.5 meters below the floor of the Great Plaza. The urn contained ashes of an unidentified organic substance, and seashells found near the lid of the urn may also have originally been contained within it. Archaeologists also found some stones (tepetates) near the urn that may have originally been remains of a cist that contained it, like the one enclosing the urn in front of Building E. Unfortunately, it was impossible to expand the excavation to discover more about the urn's context, but archaeologists suggest that it may have been deposited as an offering sealing a previous layer of construction, just as the first urn was associated with the reconstruction of the Great Plaza decades later. Delgadillo Torres, "Las urnas policromadas de Cacaxtla, Tlax. (Estudio preliminar)," 475-476; Rosalba Delgadillo Torres and Andrés Santana Sandoval, "Informe técnico sobre los trabajos de excavación, clasificación y análisis de los materiales arqueológicos 'Gran Basamento de la zona arqueológica de Cacaxtla, Tlaxcala' — durante el ańo de I985." Informe presentado al Instituto Nacional de Antropología e Historia, México. Archivo Técnico 28-42, 30-33.

58. This earlier, lower level may have been an open plaza, and because of its great depth, it may also be substantially earlier than all of the Cacaxtla paintings excavated to date. Delgadillo Torres, "Las urnas policromadas de Cacaxtla, Tlax. (Estudio preliminar)," 475-477.

59. Delgadillo Torres, "Las urnas policromadas de Cacaxtla". For building elevations relative to Great Plaza, see Geneviève Lucet Lagriffoul, "Propuesta de secuencia constructiva del Gran Basamento" (paper presented at the Primer Coloquio Internacional sobre Cacaxtla a sus treinta años de investigación, Tlaxcala, 2006). The table is reproduced in Claudia Brittenham, "The Cacaxtla Painting Tradition: Art and Identity in Epiclassic Mexico" (Ph.D. thesis, Yale University, 2008), 207.

6o. This urn was found in a small stone cist directly in front of the central axis of Building E, the building bordering the Great Plaza to the west, during the 1977 excavations. This cist was incorporated into the fill of the staircase of the building covering Building E, and 


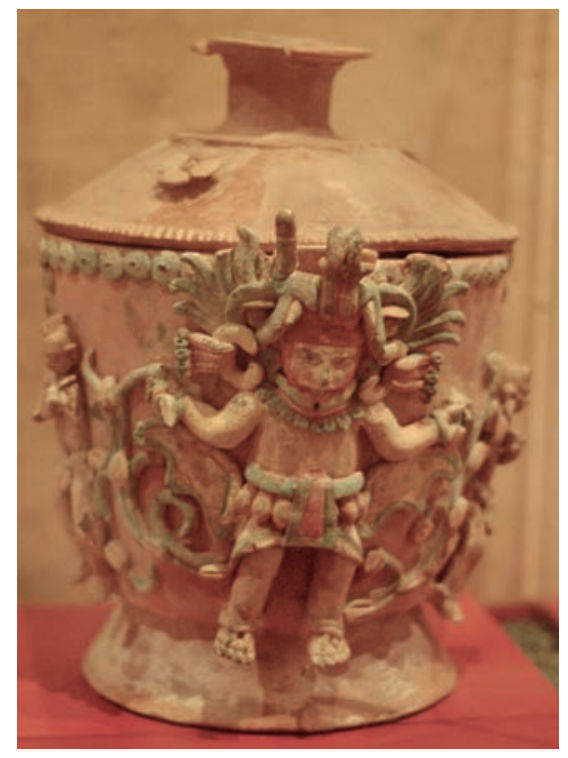

25. Cacaxtla, urn found beneath the Patio de los Altares during acropolis excavations. Central figure has butterfly wings. Museo Regional de Tlaxcala. Photo: Claudia Brittenham. Conaculta-INAH-MÉx. "Reproducción autorizada por el Instituto Nacional de Antropología e Historia."

Taken together, these two urns reveal tremendous continuity in Cacaxtla's ceramic tradition over the decades — if not a century or more-represented by 3.5 meters of continuous occupational accumulation, encompassing at least one and perhaps several renovations of the space that became the Great Plaza. One urn is contemporary with the Cacaxtla murals, while the other predates them, but both show congruity with the themes and approaches of the murals. ${ }^{61}$ These two urns have a great deal in common with the Cacaxtla paint-

archaeologists suggest that it was deposited as an offering during this phase of reconstruction of the Great Plaza, perhaps as part of the dedication of the building that covered Building E. The urn appeared to be empty when it was found, but perhaps it had initially contained perishable materials, possibly food or liquid. One of the few complete ceramics ever found at the Cacaxtla acropolis, its preservation may be attributed to its use as an offering and its placement in this cist. See López de Molina and Molina Feal, "Arqueología," 29; Delgadillo Torres, "Las urnas policromadas de Cacaxtla, Tlax.," 467-468. For the dating, see Brittenham, "The Cacaxtla Painting Tradition: Art and Identity in Epiclassic Mexico," I98-250; The Murals of Cacaxtla.

6I. Another possibility is that the urns are contemporary and the later urn was an heirloom, deposited when Building E was rebuilt. While this possibility cannot be discarded, the two urns are sufficiently different in form and content to suggest distinct moments of facture. Both, however, fit into broader Epiclasic patterns, roughly similar in vessel shape and figural 
26. Cacaxtla, urn found in front of Building $\mathrm{E}$ during acropolis excavations. Central figure has bird wings. Museo de Sitio de Cacaxtla. Photo:

(C) Marco Antonio Pacheco. Conaculta-INAHMÉx. "Reproducción autorizada por el Instituto Nacional de Antropología e Historia."

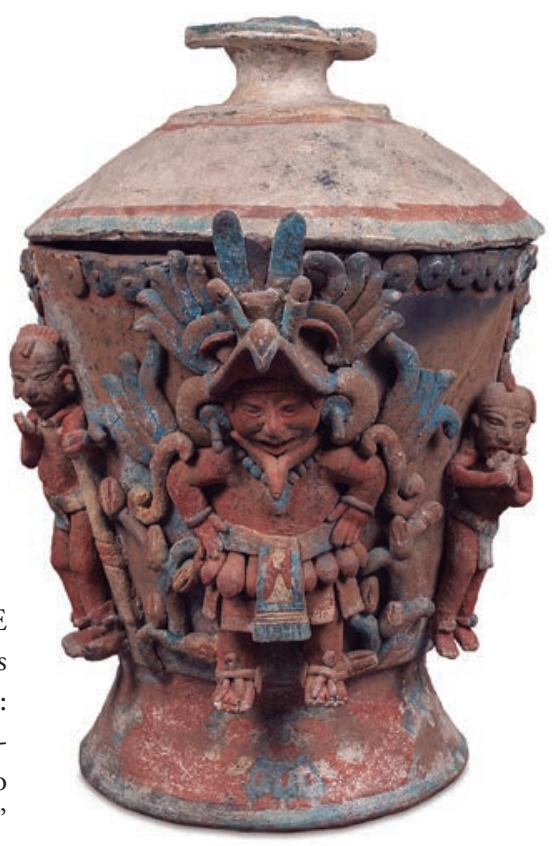

ing tradition: they use similar colors and naturalistic forms, and their subject matter seems to echo themes found in the paintings. Here we have a union of subject matter and style between paintings and ceramics that is entirely expected.

At the same time, both urns are strikingly different from the Once Señores, even though all were rendered in the same medium. Compare the treatment of the butterfly and bird headdresses, direct points of comparison between the two groups (compare fig. 25 to fig. 8 and fig. 26 to fig. I3). Each feather on the urns is individually hand-modeled, its long and flexible length and blue-green color evoking the feathers of the tropical quetzal, in contrast to the short, trimmed feathers, delimited by incision, on the Once Señores. The eyes of both bird and butterfly helmets on the urns have hooded, projecting brows, unlike either the bulging eyes of the bird headdress or the feathered eyebrows of the butterfly headdresses among the Once Señores. Beyond these

form to several urns excavated at Xochicalco; see De la Fuente, Garza Tarazona et al., La Acrópolis de Xochicalco, I30, 178, 199. 
dramatically different approaches to rendering the same subjects, the bodies are treated differently, the arms more flexible, more flesh exposed, the oliva shells at their waists smaller and closer to scale. The treatment of the physiognomy of the human figures also differs considerably. The Once Señores have narrow mask-like faces, almond-shaped eyes, fleshy beaky noses, and thick lips framing the upper row of teeth. On the other hand, the urn figures have broader faces and more finely rendered features, such as an eyebrow ridge, high cheekbones, and a more naturalistic treatment of the mouth. There are striking differences in composition as well, with the Once Señores far more three-dimensional in their modeling, though this may partly be due to differences in function. It is notable, however, that the unusual iconography of the earlier urn, with its butterfly headdress and jaguar-spotted bat or butterfly wings, presents greater continuity with the Once Señores (compare fig. 25 to fig. 9). While clearly part of the Cacaxtla tradition, the Once Señores present major stylistic and iconographic disjunctions with the other art known from Cacaxtla.

\section{Conclusion: Implications for Cacaxtla}

How can we account for the stark differences between the Once Señores and the other art known from Cacaxtla? One possibility is that they represent contemporary, perhaps even complementary, strategies for engaging with the outside world. While the Once Señores were oriented largely towards Teotihuacan, the paintings looked towards the exotic tropical lands of the souththe Maya, Gulf Coast, and Oaxaca regions. The substantive differences in monumental architecture and material culture between the neighboring hills of Cacaxtla and Xochitécatl during their Epiclassic occupation exemplify a synchronic diversity at the site that has been interpreted as indicating a functional difference between elite residential and ceremonial areas, respectively. ${ }^{62}$ The same differentiation might apply to the Once Señores, but because their

62. Mari Carmen Serra Puche and Jesús Carlos Lazcano Arce, "Urban Configuration at Cacaxtla-Xochitécatl," in El urbanismo en Mesoamérica/Urbanism in Mesoamerica, eds. Alba Guadalupe Mastache, William T. Sanders et al., vol. 2 (Mexico City and University Park, PA: Instituto Nacional de Antropología e Historia and The Pennsylvania State University, 2008), I53; Vida Cotidiana Xochitécatl-Cacaxtla, 37-53. But see also Brittenham, The Murals of Cacaxtla. 
original location is unknown it is unclear if they actually formed part of the elite core of Cacaxtla or if they might have pertained to another sector.

Another possibility is that the Once Señores are substantively earlier than the Cacaxtla murals and represent an alternative approach to public art during Cacaxtla's Classic period occupation. Though the lack of datable ceramics or stratigraphic associations between the deposit in which they were found and the rest of the Cacaxtla acropolis make it impossible to prove this definitely, we favor this interpretation for several reasons. Teotihuacan was already in collapse by the time that the murals visible at Cacaxtla today were created. Current consensus suggests that Teotihuacan's collapse occurred earlier than previously believed, around A.D. 600-650 if not earlier. ${ }^{63}$ At the same time, reanalysis of Cacaxtla's stratigraphy and recalibration of its radiocarbon dates suggests that the visible architecture and the murals are later than previously reported, firmly eighth and ninth century in date, although the painting tradition did likely begin in the seventh or eighth century. ${ }^{64}$ Given this gap in time, it is not clear why Cacaxtlans would have continued making art that cited Teotihuacan once the city was already a distant and troubled memory; indeed, Teotihuacan's legacy in Mesoamerica may have been radioactive for several centuries before experiencing any revivals. Very little art made anywhere in Mesoamerica in the sixth or early seventh century cites Teotihuacan; only after the city's memory has faded do revivals, like the eighthcentury warrior stelae of Piedras Negras, engage with the Teotihuacan past. ${ }^{65}$

Furthermore, many of the closest formal parallels for the Once Señores, such as the Escuintla incensarios, Oaxaca urns, and the Cerro de las Mesas Huehueteotl, are also early, corresponding to Teotihuacan's apogee in

63. Evelyn Rattray, Teotihuacan: Ceramics, Chronology and Cultural Trends (Mexico City and Pittsburgh: Instituto Nacional de Antropología e Historia and University of Pittsburgh, 200I), 407, 435. For an even earlier date for Teotihuacan's collapse, ca. A.D. 550, see López Luján, Filloy et al., "The Destruction of Images in Teotihuacan," 300.

64. For the dating, see Brittenham, "The Cacaxtla Painting Tradition: Art and Identity in Epiclassic Mexico," I98-250; The Murals of Cacaxtla, Appendix.

65. The warrior stelae of Piedras Negras date from A.D. 703-767; Andrea Stone, "Disconnection, Foreign Insignia, and Political Expansion: Teotihuacan and the Warrior Stelae of Piedras Negras," in Mesoamerica After the Decline of Teotihuacan. Other late seventh-mideighth century revivals of Teotihuacan iconography at Tikal, Yaxchilán, and Copán, among other sites, are surveyed in Simon Martin and Nikolai Grube, Chronicle of the Maya Kings and Queens, 2nd ed. (London: Thames \& Hudson, 2008), 45, 46, 51, 60, I25-I26, I29, 20I202, 207-208. 
the fourth and fifth centuries. ${ }^{66}$ Although none of them are exact parallels, we suggest that the Once Señores may have emerged from the same sort of political conditions and social processes as these works, during a moment when Teotihuacan was a powerful force in Mesoamerica, a force to be feared, courted, or emulated.

Recently, archaeologist Andrés Santana Sandoval has suggested that Cacaxtla's true apogee may be much earlier than previously thought, during the Tenanyecac phase or A.D. I00-650, contemporary with Teotihuacan. ${ }^{67}$ This earlier phase lies buried beneath the present acropolis and has barely been touched by excavations. Because of the way that the acropolis grew over time, sealing old constructions under new, we are more familiar with Cacaxtla's late history as a hilltop citadel during the Epiclassic period, the era when the murals were painted. Yet this moment yields only a partial picture of Cacaxtla's history. Centuries of continuous occupation and accumulated construction account for over 90\% of the twenty-five meter rise that is the Cacaxtla acropolis, but less than the top third of this mound has been excavated. ${ }^{68} \mathrm{~A}$ core sample from the Patio Hundido in the center of the acropolis went down over 16 meters without hitting bedrock, nearly half of it beyond the depth of excavations in the center of the acropolis. ${ }^{69}$ Because this area is difficult to ex-

66. For a re-evaluation of the dating of the Cerro de las Mesas figure, see Barbara L. Stark, Settlement Archaeology of Cerro de la Mesas, Veracruz, Mexico (Los Angeles: University of California, Institute of Archaeology, I99I), 9-I I.

67. Andrés Santana Sandoval, "Contribución al establecimiento de una secuencia cronológica cultural en Cacaxtla, Tlaxcala” (tesis de licenciatura, México City: Escuela Nacional de Antropología e Historia, I990), 62-65; "La iconografía y arqueología de Cacaxtla: su aportación al conocimiento de sus creadores," in Memorias del Primer Coloquio Internacional Cacaxtla a sus treinta años de investigación (Tlaxcala: Centro Regional InAH-Tlaxcala, 2007), 78; El santuario de Cacaxtla (Mexico City: Trillas, 201 I), 49-56.

68. Pedro Armillas, "Los olmeca-xicalanca y los sitios arqueológicos del suroeste de Tlaxcala," Revista Mexicana de Estudios Antropológicos 8 (1946): I40; López de Molina and Molina Feal, "Arqueología," 33; Andrés Santana Sandoval, "La iconografía y la arqueología de Cacaxtla y sus aportaciones al conocimiento de sus creadores" (Conferencia magistral at the Primer Coloquio Internacional sobre Cacaxtla a sus treinta años de investigación, Tlaxcala, 2006).

69. López de Molina and Molina Feal, "Arqueología," 33; "Proyecto Cacaxtla. Informe 1977." Informe presentado al Instituto Nacional de Antropología e Historia, México, 1977. Archivo Técnico 28-6. Since the Patio Hundido lies approximately 6 meters above the Great Plaza, and the South Plaza another 2 meters below that, this test core still reveals at least 
cavate without jeopardizing the stability of the paintings and destroying later construction, it remains difficult to understand Cacaxtla's earliest occupation.

However, radiocarbon dates from test pits surrounding the acropolis suggest that Cacaxtla's Classic period occupation may have been more considerable than has been previously recognized. ${ }^{70}$ Furthermore, excavations

another 8 meters of human construction in the central part of the acropolis beyond what has been extensively excavated.

70. Three of the radiocarbon measures taken at Cacaxtla date to the Classic period. Samples 6, 7, and 8 came from the lowest layers of test pits to the west, east, and south of the acropolis, respectively, yielding recalibrated dates ranging between the first and sixth centuries A.D., "Proyecto Cacaxtla. Informe 1977." Informe presentado al Instituto Nacional de Antropología e Historia, México, 1977. Archivo Técnico 28-6, 23-29; Santana Sandoval, "Contribución al establecimiento de una secuencia cronológica cultural en Cacaxtla, Tlaxcala," 62-65. It is significant that these samples reflect substantially earlier dates than the samples taken from the upper layers of the Cacaxtla acropolis, suggesting that Cacaxtla may have had a substantial Classic occupation between the second and sixth centuries A.D., Santana Sandoval "La iconografía y la arqueología de Cacaxtla y sus aportaciones al conocimiento de sus creadores"; Brittenham, The Murals of Cacaxtla. In this respect, Cacaxtla seems to have differed from the neighboring hills of Xochitécatl and Nativitas, which were completely abandoned between A.D. 200 and A.D. 650. See Jesús Carlos Lazcano Arce and Bernardo Adán Flores Bonilla, "Excavaciones arqueológicas en el sitio de Nativitas, Tlaxcala. CacaxtlaXochitécatl. Más allá del templo y el palacio," in Memorias del Primer Coloquio Internacional Cacaxtla a sus treinta años de investigación (Tlaxcala: Centro Regional INAH-Tlaxcala, 2007), 226-23I; Mari Carmen Serra Puche and Jesús Carlos Lazcano Arce, "El Epiclásico en el valle Puebla-Tlaxcala y los sitios de Cacaxtla-Xochitécatl-Nativitas," in Reacomodos demográficos del Clásico al Posclásico en el centro de México, ed. Linda Manzanilla (Mexico City: Universidad Nacional Autónoma de México-Instituto de Investigaciones Antropológicas, 2005), 293; Vida Cotidiana Xochitécatl-Cacaxtla, 6I-67.

Although Serra and colleagues suggest that the entire Cacaxtla-Xochitécatl complex was abandoned during the Early Classic period, the radiocarbon and ceramic evidence seems to suggest that the residential areas of Cacaxtla were continuously occupied from the Late Preclassic on. See Abascal, Dávila et al., "La arqueología del sur-oeste de Tlaxcala (primera parte)," 7-2I; Diana López de Molina, "Un informe preliminar sobre la cronología de Cacaxtla," in Interacción cultural en México central, eds. Evelyn Childs Rattray, Jaime Litvak King et al. (Mexico City: Universidad Nacional Autónoma de México-Instituto de Investigaciones Antropológicas, I98I), I70-172; López de Molina and Molina Feal, "Arqueología," I8; Daniel Molina Feal, "La investigación arqueológica en Cacaxtla, Tlaxcala," Boletín del Museo del Hombre Dominicano 7, no. 9 (1978): 56; Andrés Santana Sandoval, "Excavaciones en la periferia de Cacaxtla, Tlaxcala," in Investigaciones recientes en el área maya: XVII Mesa Redonda, Sociedad Mexicana de Antropología, San Cristóbal de las Casas, Chiapas, 2 I-27 junio 198I (Mexico City: Sociedad Mexicana de Antropología, I984), 269-270. 


\section{CLAUDIA BRITTENHAM - DEBRA NAGAO}

around the periphery of the acropolis, to install drainage systems and the pillars of the roof that presently covers the site, confirm the impression of centuries of continuous construction and intense rebuilding. ${ }^{7 \mathrm{I}}$

Just as the figural ceramics seem to point to a closer engagement with Teotihuacan art and iconography, so does some of the earliest architecture so far discovered at Cacaxtla. During excavations for the roof that covers the site, a talud-tablero building with Teotihuacan-style proportions was found. Like the ceramics under consideration, this building is more similar to Teotihuacan than it is to later Cacaxtla constructions, which have much more elongated proportions..$^{72}$ These later Cacaxtla talud-tableros provide a faint citation of Teotihuacan, like the aquatic borders in the murals, but insist on defining a local, cosmopolitan identity oriented to other parts of Mesoamerica. However, the early talud-tablero building and the Once Señores suggest that the Cacaxtlans did not always shun Teotihuacan art, as the rhetoric of the paintings would like to suggest.

It seems increasingly possible that Cacaxtla had an early florescence during which it employed Teotihuacan artistic conventions, and only later, after Teotihuacan's collapse, turned to Maya style to differentiate itself from its former alignment. Whatever the chronology, the comparison of the rhetoric of painting and ceramics proves that the use of artistic style to construct civic identity at Cacaxtla was a complex and dynamic process. $\$$

71. Lino Espinoza García and Pedro Ortega Ortiz, "Informe, Cacaxtla, Tlaxcala, 19851987." Informe presentado al Instituto Nacional de Antropología e Historia, México. Archivo Técnico 28-46; Cristina Sánchez del Real, Cacaxtla: Un esfuerzo común para la preservación de nuestro patrimonio cultural (Tlaxcala: Gobierno del Estado de Tlaxcala, 1987).

72. See Cristina Sánchez del Real, Cacaxtla: Un esfuerzo común para la preservación de nuestro patrimonio cultural; Brittenham, The Murals of Cacaxtla, figs. I6 and 38. 